\title{
Early Signaling Events Induced by Elicitors of Plant Defenses
}

\author{
Angela Garcia-Brugger, Olivier Lamotte, Elodie Vandelle, Stéphane Bourque, David Lecourieux, \\ Benoit Poinssot, David Wendehenne, and Alain Pugin
}

UMR 1088 INRA/CNRS 5184/Université de Bourgogne Plante Microbe Environnement (PME), INRA, 17 rue Sully, BP 86 510, 21065 Dijon cedex, France

Submitted 6 October 2005. Accepted 14 March 2006.

\begin{abstract}
Plant pathogen attacks are perceived through pathogenissued compounds or plant-derived molecules that elicit defense reactions. Despite the large variety of elicitors, general schemes for cellular elicitor signaling leading to plant resistance can be drawn. In this article, we review early signaling events that happen after elicitor perception, including reversible protein phosphorylations, changes in the activities of plasma membrane proteins, variations in free calcium concentrations in cytosol and nucleus, and production of nitric oxide and active oxygen species. These events occur within the first minutes to a few hours after elicitor perception. One specific elicitor transduction pathway can use a combination or a partial combination of such events which can differ in kinetics and intensity depending on the stimulus. The links between the signaling events allow amplification of the signal transduction and ensure specificity to get appropriate plant defense reactions. This review first describes the early events induced by cryptogein, an elicitor of tobacco defense reactions, in order to give a general scheme for signal transduction that will be use as a thread to review signaling events monitored in different elicitor or plant models.
\end{abstract}

Additional keywords: ion fluxes, protein kinase.

In the course of their development, plants have to face a wide range of potential pathogens, including viruses, bacteria, fungi, oomycetes, nematodes, and insects. However, disease is an exception rather than a rule and infections occur in only limited cases. Preformed physical and chemical barriers such as cuticles, cell walls, and constitutively produced antimicrobial compounds protect the plant against most attempted invasions (nonhost interactions). However, when a putative pathogen is able to get over these barriers (host interaction) and if the plant recognizes the invader, a rapid induction of defense responses by the resistant plant can prevent the bioagressor from developing (incompatible interaction). Disease spreads only in susceptible plants (compatible interaction) which are unable to recognize the pathogen or respond too slowly. In many plants, resistance to diseases is known to be genetically

Corresponding author: Angela Garcia-Brugger;

E-mail: Angela.Garcia-Brugger@dijon.inra.fr

Present address of D. Lecourieux: UMR CNRS 6161 "Transport des Assimilats," Bâtiment de Botanique, 40 av. du recteur Pineau, 86022 Poitiers cedex, France. controlled by plant resistance $(R)$ genes and pathogen avirulent (Avr) genes (gene-for-gene concept) (Flor 1947). It also has been postulated that $R$ gene products act as receptors of Avr proteins, either directly or indirectly (elicitor-receptor model) (Keen et al. 1972), their molecular interaction leading to the initiation of a signaling cascade responsible for defense response activation. However, for most matching Avr-/R-protein pairs, Avr protein binding has not been demonstrated yet and, at the moment, this model is limited to a few interactions (Jia et al. 2000; Leister and Katagiri 2000; Scofield et al. 1996; Tang et al. 1996). Based on the observation that many Avr signals appear to have a role in pathogen virulence, particularly in hosts that do not express the corresponding $R$ gene, the "guard model" was proposed for $R$ gene function. This model predicts that Avr proteins are effectors that interact with target plant proteins to manipulate host processes in favor of the pathogen, inhibiting, for instance, the basal defense level. In this scenario, $\mathrm{R}$ proteins are guardians that recognize the target and Avr protein complexes. This recognition then could initiate the plant defense response (Dangl and Jones 2001; McDowell and Woffenden 2003; Nimchuk et al. 2003). However, triggering resistance is not always due to specific Avr products which activate defense responses in cultivars possessing the matching resistance genes but, instead, proceeds from the action of general elicitors, able to activate defenses in different cultivars of one or many species. Elicitors include compounds belonging to different chemical families: proteins, glycoproteins, glycans, lipids, and synthetic molecules. They are constituents of the pathogen or secreted by it, or they are released from the plant or pathogen cell walls by hydrolytic enzymes from the pathogen or the plant. The most studied elicitors are indicated in Table 1 .

Early signal transduction pathway studies with elicitors revealed striking similarities between plants and animals in molecules used to perceive and transmit signals associated with invaders. These observations highlight the conservation of a defense-related signaling system in the different living kingdoms throughout evolution that have led to the innate immunity system (Dangl and Jones 2001; Nürnberger et al. 2004). Early events, such as protein phosphorylation or activation of plasma membrane proteins, mobilize or generate directly or indirectly diverse signaling molecules (such as free calcium, nitric oxide [NO], active oxygen species [AOS]) which regulate many processes, interconnecting branch pathways that amplify and specify the physiological response through transcriptional and metabolic changes. In particular, the early activation of genes involved in phytohormone biosynthesis modifies the hor- 
monal balance, leading to the appropriate transcriptome changes. Studies with different plant-pathogen systems have shown that plants can activate distinct defense pathways involving different regulators, depending on the types of parasites (Ton et al. 2002). The ethylene- (ET) and jasmonic acid (JA)-dependent defense responses seem to be activated by necrotrophic pathogens, whereas the salicylic acid (SA)-dependent response is triggered by biotrophic pathogens (Thomma et al. 2001). Some studies indicate that ET or JA and SA responses inhibit each other, suggesting that crosstalk between the pathways exist, enabling the plant to adapt the response depending on the types of pathogen (Reymond and Farmer 1998; Spoel et al. 2003). Genetic studies in Arabidopsis have made it possible to identify numerous genes involved in both pathways and how they may be interconnected (Lorrain et al. 2003). At the end, microbe- or elicitor-induced signal transduction pathways lead to i) the reinforcement of cell walls; ii) the production of antimicrobial metabolites (phytoalexins), pathogenesis-related (PR) proteins and enzymes of oxidative stress protection; iii) lignification; and, often, iv) the hypersensitive response (HR), a form of programmed host cell death at the infection site associated with limited pathogen development (Lorrain et al. 2003). These defense responses might trigger in the whole plant a long-lasting systemic acquired resistance (SAR), which is dependent on SA and effective against a large spectrum of pathogens (Ricci 1997).

The present review focuses on early molecular events that have been identified after elicitor or pathogen recognition, recognition being covered in recent reviews (Nürnberger et al. 2004). This first set of reactions leads to a complex change in gene expression, enzymatic activity, and metabolic modifications; the latter modifications are not described here. Early signaling events induced by the oomycete elicitor cryptogein in tobacco cells is presented before discussing and detailing the major early signaling events and their occurrence in different models.

\section{Signaling pathway triggered \\ by the elicitor cryptogein in tobacco cells.}

Cryptogein is a $10-\mathrm{kDa}$ protein secreted by Phytophthora cryptogea; it induces HR and SAR in tobacco plants (Ricci 1997). Early signaling events were mostly deciphered using tobacco cell suspensions (Fig. 1); however, numerous effects, including NO production, mitogen-activated protein kinase (MAPK) activation, cell death, and gene expression, were confirmed in whole plants. Cryptogein binding studies and crosslinking experiments to a potential receptor were performed on tobacco plasma membrane preparations; the characterized binding site is a glycosylated heterodimer protein (Bourque et al. 1999). The perception step is followed by activation of protein kinases (PK) or inhibition of protein phosphatases (PP) that, in turn, trigger the $\mathrm{Ca}^{2+}$ influx (Lecourieux-Ouaked et al. 2000). Within the first $5 \mathrm{~min}$, nearly 20 phosphoproteins showed an increase in phosphorylation status, as visualized by two-dimensional electrophoresis analysis of in vivo-labeled proteins (Lecourieux-Ouaked et al. 2000). Extracellular $\mathrm{Ca}^{2+}$ influx, depending on PK activation, triggers AOS production (Tavernier et al. 1995), MAPK activation (Lebrun-Garcia et al. 1998), PK activation upstream of the NO production (Lamotte et al. 2004), anion effluxes and plasma membrane depolarization (Pugin et al. 1997; Wendehenne et al. 2002), glucose (Glc) import inhibition (Bourque et al. 2002), microtubule depolymerization (Binet et al. 2001), and may lead to the $\mathrm{H}^{+}$-ATPase inhibition. These events can all be monitored within the first hour. MAPK activation is independent of AOS and NO production (Lamotte et al. 2004; Lebrun-Garcia et al. 1998) and anion effluxes (Wendehenne et al. 2002). Superoxide ions are generated by the NADPH oxidase NtRbohD (Simon-Plas et al. 2002), which requires NADPH provided by the pentose phosphate pathway (Pugin et al. 1997). The NADPH conversion contributes to the cytoplasmic $\mathrm{pH}$ acidification (Pugin et al. 1997). $\mathrm{O}_{2}^{-}$is converted by superoxide dismutase (SOD) into $\mathrm{H}_{2} \mathrm{O}_{2}$, which induces a subsequent extracellular $\mathrm{Ca}^{2+}$ influx and a rise in $\left[\mathrm{Ca}^{2+}\right]_{\text {cyt }}$ and $\left[\mathrm{Ca}^{2+}\right]_{\text {nuc }}$ (Lecourieux et al. 2002, 2005). The $\left[\mathrm{Ca}^{2+}\right]_{\text {cyt }}$ rise is also due to release from internal $\mathrm{Ca}^{2+}$ pools through $\mathrm{IP}_{3^{-}}$and cADPR-regulated $\mathrm{Ca}^{2+}$ channels (Lamotte et al. 2004; Lecourieux et al. 2002), whereas the $\left[\mathrm{Ca}^{2+}\right]_{\text {nuc }}$ depends on $\mathrm{IP}_{3}$-dependent calcium channels and is not due to calcium diffusion from the cytosol (Lecourieux et al. 2005). cADPR could be produced in response to NO (Durner et al. 1998; Lamotte et al. 2004). Anion effluxes may participate in i) the plasma membrane depolarization (Pugin et al. 1997), which is responsible for the amino acid import inhibition (Valine [Val] was used as a marker) and the $\mathrm{K}^{+}$efflux (Bourque et al. 2002; Pugin et al. 1997) and ii) the activation of the NADPH oxidase and cell death (Wendehenne et al. 2002). Protein phosphorylation, the first identified event in the cryptogein signal transduction pathway, also happens throughout the cryptogein signal transduction pathway. Although a few PKs have been identified, among them the SIPK and WIPK MAPKs (Lebrun-Garcia et al. 1998; Zhang et al. 1998), there is much evidence for cytoplasmic and nuclear $\mathrm{Ca}^{2+}$ dependent PK activation as well as for $\mathrm{Ca}^{2+}$-independent phosphorylations (Lecourieux-Ouaked et al. 2000; our unpublished results). Cell death and gene expression are under control of the boxed signaling events presented in Figure 1 (Binet et al. 2001; Lamotte et al. 2004; Rustérucci et al. 1999; Wendehenne et al. 2002; Zhang et al. 1998). The study of cryptogein's effect in tobacco revealed that many steps are controlled by a primary calcium influx; later, AOS and NO productions induce a calcium release from internal pools that will prime other signaling events. Many components of the transduction pathway

Table 1. Selection of general or specific elicitors described in plant defense reactions

\begin{tabular}{|c|c|c|c|}
\hline Elicitors & Origin & Host & References \\
\hline Oligogalacturonides & Pectic fragments from plant cell wall & General & D’Ovidio et al. 2004 \\
\hline Chitosan & Chitin fragments from fungus cell wall & General & Rabea et al. 2003 \\
\hline$\beta$-Heptaglucosan & $\begin{array}{l}\text { Component of the mycelia cell walls of Phytophthora megasperma and } \\
\text { other oomycetes }\end{array}$ & Soybean & Ebel 1998 \\
\hline Lipopolysaccharides & Gram-negative bacteria & General & Scheidle et al. 2005 \\
\hline Elicitins (cryptogein) & Proteins from oomycetes (from Phytophthora cryptogea) & Nicotianae & Ricci 1997 \\
\hline Avr2, Avr4, Avr5, Avr9 & Products of the corresponding avr genes of Cladosporium fulvum & Tomato race specific & Joosten and de Wit 1999 \\
\hline Pep-13 & $\begin{array}{l}\text { Oligopeptide of } 13 \text { amino acids within a } 42-\mathrm{kDa} \text { transglutaminase secreted } \\
\text { by Phytophthora sojae }\end{array}$ & Parsley & Brunner et al. 2002 \\
\hline Flg22 & 22-amino acid N-terminal fragment of bacterial flagellin & General & Zipfel et al. 2004 \\
\hline Xylanase & Trichoderma spp. & General & Enkerli et al. 1999 \\
\hline BcPG1 & Endopolygalacturonase from Botrytis cinerea & Grapevine & Poinssot et al. 2003 \\
\hline AvrPto & Pseudomonas syringae pv. tomato & Tomato race specific & Scofield et al. 1996 \\
\hline
\end{tabular}


are still unknown. For that reason, it is interesting to review the signaling events induced with different elicitors to determine the common and unique steps in each pathway.

PKs and phosphorylated proteins involved in plant defense reactions.

The major routes of signaling pathways in plant cells follow processes similar to those described in other living kingdoms, though with some differences. For example, calmodulin (CaM)-like domain protein kinases (CDPK) form a large family of PKs sensing $\mathrm{Ca}^{2+}$ in plants due to their carboxy-terminal CaM-like sequences. CDPKs are not found in animals, whereas $\mathrm{CaM}$-dependent protein kinases (CaMKs) and protein kinase $\mathrm{C}$ are under-represented or missing in plants (Hrabak et al. 2003). Five plant PK classes have been defined with several subclasses (PlantsP: Functional Genomics of Plant Phosphorylation website). Many reports implicate PKs in plant defense reactions; most of them belong to the CDPK and MAPK families.

After elicitor perception, PK activation may be the earliest induced event; this should be the case for those elicitors which are readily recognized by proteins such as receptor-like kinases (RLKs), which are cytoplasmic or plasma membrane localized. For example, flagellin, a bacterial elicitor, interacts with an Arabidopsis RLK named flagellin-sensing locus 2 (FLS2), a transmembrane protein with a functional intracellular PK domain and an extracellular leucine-rich repeat domain (Gomez-Gomez and Boller 2000). The flagellin signal is fur- ther transduced into the intracellular space by activation of a MAPK cascade, typically formed by at least three interlinked PKs: the MAPKKK or MEKK, MAPKK or MEK, and MAPK. The activation of the MAPK cascade induced by flagellin involves MEKK1, MKK4/MKK5, and two MAPKs, MPK3 and MPK6 (Asai et al. 2002). Xa21 also belongs to the same receptor class as FLS2; it mediates race-specific resistance of rice to Xanthomonas oryzae pv. oryzae. Biochemical analysis of its PK domain showed autophosphorylation of 27 phosphopeptides obtained after trypsin digestion of the labeled PK domain (Liu et al. 2002). Signaling elements downstream of Xa21 presently are not known. The Pseudomonas syringae pv. tomato AvrPto elicitor (Table 1) is recognized by the cytoplasmic receptor kinase Pto (Scofield et al. 1996; Tang et al. 1996) which, in turn, interacts with several proteins, including the Pti1 PK and numerous transcription factors, Pti4, Pti5, and Pti6, among which Pti4 is directly phosphorylated by Pto $(\mathrm{Gu}$ et al. 2000). Also characterized downstream of the AvrPto-Pto interaction, a complete potential MAPK cascade has been proposed based on biochemical evidence linking several members of the MAPK module, comprising two tomato MAPKs, LeMPK2 and LeMPK3; two MAPKKs, LeMKK2/LeMKK4; and a MAPKKK, LeMAPKKK $\alpha$, (Pedley and Martin 2004). Recently, the Avr9/Cf9-induced kinase 1 (ACIK1) gene has been identified among a collection of rapidly elicited tobacco genes. Database searches have revealed that its kinase domain is homologous to those of the RLKs. Virus-induced gene si-

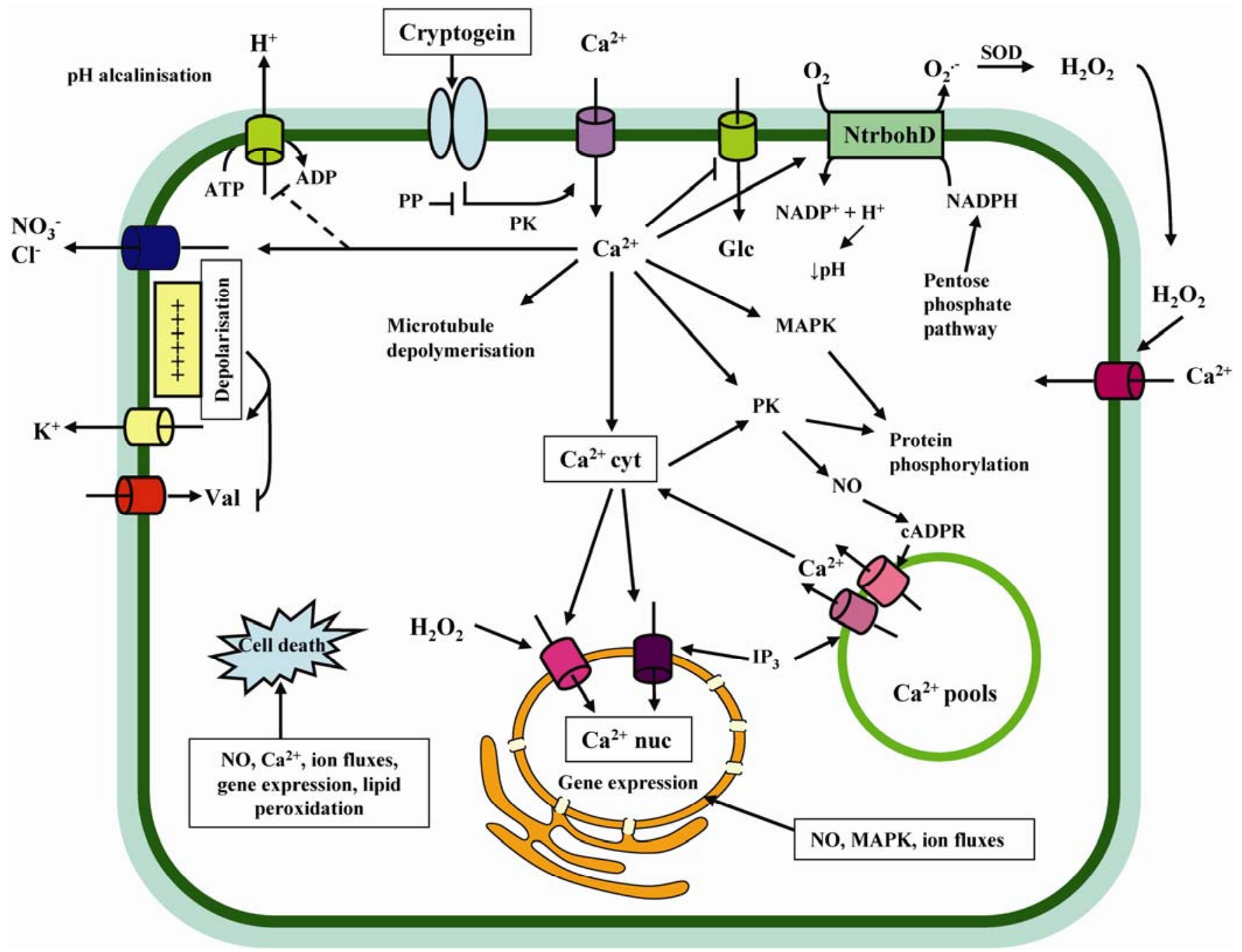

Fig. 1. Schematic representation of cryptogein-induced signal transduction. 
lencing (VIGS) of ACIK1 resulted in the reduction of the HR mediated by Avr9 and Avr4 elicitors in N. benthamiana plants carrying the $C f 9$ and $C f 4$ resistance genes, respectively, but had no effect on other resistance/Avr systems such as $\mathrm{Pto} /$ AvrPto, RX/Potato virus $\mathrm{X}$, and N/Tobacco mosaic virus (Rowland et al. 2005).

Relationships between PKs and calcium signaling. Elicitor perception often is followed rapidly by a $\mathrm{Ca}^{2+}$ influx and intracellular $\mathrm{Ca}^{2+}$ signals, such as those generated by the cryptogein elicitor in tobacco cells (Fig. 1) (Kadota et al. 2004; Lecourieux et al. 2002; Tavernier et al. 1995). These signals, in turn, could activate CDPKs. Indeed, it has been shown that many in vivo protein phosphorylations depend on a calcium influx into tobacco cells treated with cryptogein (Lecourieux-Ouaked et al. 2000). Different CDPK transcripts accumulate in tobacco, maize, and tomato tissues upon pathogen infection (Chico et al. 2002; Murillo et al. 2001; Yoon et al. 1999). CDPK activities have been reported in transgenic tobacco expressing the $C f 9$ resistance gene and challenged by the Avr9 elicitor; using PK inhibitors, the authors proposed that CDPKs act upstream of $\mathrm{H}_{2} \mathrm{O}_{2}$ production or in an $\mathrm{H}_{2} \mathrm{O}_{2}$-independent signaling pathway (Romeis et al. 2000). Two tobacco CDPKs, NtCDPK3 and $\mathrm{NtCDPK} 2$, have been isolated; they are transcriptionally upregulated in response to elicitation and osmotic stresses. $\mathrm{Si}$ lencing of the NtCDPK2 gene compromises Avr9/Cf-9-mediated HR but, interestingly, did not modify the activity of two tobacco MAPKs, SIPK and WIPK, also induced by Avr9 (Romeis et al. 2001), indicating that the two MAPKs are not downstream of NtCDPK2. Another tobacco CDPK, $\mathrm{NtCDPK} 1$, is involved in response to wounding, phytohormone signaling, high salt, and fungal elicitor treatments (Yoon et al. 1999). In addition to the regulation of AOS production, CDPKs may be implicated in $\mathrm{H}^{+}$fluxes induced by elicitors by regulating $\mathrm{H}^{+}$-ATPase activities (Schaller and Oeckling 1999; Xing et al. 1996). Although both phenylalanine ammonia lyase (PAL) and NADPH oxidase have been reported as potential substrates for pathogen-induced CDPKs (Allwood et al. 2002; Xing et al. 2001), the identities of proteins phosphorylated by CDPKs during defense response remain largely unknown.

As shown before, plant defense reactions commonly are associated with MAPK modules. MAPKs are stimulated not only during defense reactions but also in response to many stresses such as wounding, salt, temperature, and oxidative stresses (Jonak et al. 2002). Direct connections between $\mathrm{Ca}^{2+}$, CDPKs and MAPKs have not been established; however, MAPK activation is compromised when the extracellular calcium influx is blocked by $\mathrm{Ca}^{2+}$ channel blockers or $\mathrm{Ca}^{2+}$ chelators in tobacco cells treated with cryptogein (Fig. 1), in transgenic Cf9tobacco cells treated with the Avr9 elicitor, and in rice cells treated with Trichoderma viride xylanase (Kurusu et al. 2005; Lebrun-Garcia et al. 1998; Romeis et al. 1999). Interestingly, overexpression of the rice two-pore channel 1 (OsTPC1), a putative voltage-gated $\mathrm{Ca}^{2+}$-channel, is correlated with enhanced HR and activation of the rice MAPK OsMPK2 (Kurusu et al. 2005). Voltage pulse application or treatment with an elicitor preparation of Fusarium oxysporum lycopersici in tomato cells both induced MAPK activities dependent on calcium influx, but only voltage-induced MAPK activities were inhibited by nifedipine, a voltage-gated calcium channel inhibitor, suggesting that different subsets of MAPK are activated by voltage pulse and elicitors (Link et al. 2002). However, $\mathrm{Ca}^{2+}$ influx is not always a prerequisite for MAPK activation; tobacco cells exposed to the Pseudomonas syringae pv. phaseolicola harpin or grapevine cells elicited with the Botrytis cinerea endopolygalacturonase 1 (BcPG1) (Table 1) transduce the elicitor signal through MAPK activation independently of extracellular $\mathrm{Ca}^{2+}$ influx (Lee et al. 2001; Vandelle et al. 2006).
Relationships between MAPK activation and AOS production. Pharmacological inhibition of AOS production indicated that MAPK activation is independent of upstream AOS in different plant/elicitor systems; for example, tobacco cells/cryptogein, Cf9 transgenic tobacco cells/Avr9, and parsley cells/ Pep13 (Lebrun-Garcia et al. 1998; Ligterink et al. 1997; Romeis et al. 1999). In tobacco or Arabidopsis, constitutive expression of the MAPKKs NtMEK2 and AtMEK4/5 induces $\mathrm{H}_{2} \mathrm{O}_{2}$ production (Ren et al. 2002). Alternatively, exogenous application of $\mathrm{H}_{2} \mathrm{O}_{2}$ or $\mathrm{NO}$ in tobacco and Arabidopsis cells activates MAPKs (Clarke et al. 2000; Desikan et al. 2001a; Kumar and Klessig 2000); two MAPKKKs, Arabidopsis ANP1 and alfalfa OMTK1, also are activated by $\mathrm{H}_{2} \mathrm{O}_{2}$ (Kovtun et al. 2000; Nakagami et al. 2004). In $\mathrm{H}_{2} \mathrm{O}_{2}$-treated Arabidopsis seedlings, a Ser/Thr PK, OXI1, is stimulated and required for full activation of AtMPK3 and AtMPK6 (Rentel et al. 2003). $\mathrm{H}_{2} \mathrm{O}_{2}$ also induces the expression of the NDP kinase 2 gene in Arabidopsis plants; the protein NDPK2 interacts with two $\mathrm{H}_{2} \mathrm{O}_{2}$-activated MAPKs, AtMPK3/6, resulting in reduced AOS production via the transient expression of antioxidant and protective genes under the control of MAPKs (Moon et al. 2003). In conclusion, AOS production might not be necessary to activate MAPKs during elicitor treatments; however, because exogenous $\mathrm{H}_{2} \mathrm{O}_{2}$ is able to activate MAPKs, AOS may participate in a positive MAPK activation feedback with the final outcome of either reducing or increasing AOS production (Moon et al. 2003; Ren et al. 2002). However, it remains to be demonstrated that exogenously applied $\mathrm{H}_{2} \mathrm{O}_{2}$ or endogenous $\mathrm{H}_{2} \mathrm{O}_{2}$ play equivalent roles, with the added difficulty of comparing $\mathrm{H}_{2} \mathrm{O}_{2}$ levels in particular cellular locations.

MAPK implications in defense responses. Loss- or gain-offunction studies of various members of the MAPK module mostly indicate a positive role of MAPKs in the transcriptional regulation of defense genes and disease resistance in tobacco and Arabidopsis (Asai et al. 2002; Ekengren et al. 2003; Jin et al. 2002, 2003; Kim and Zhang 2004; Liu et al. 2004; Menke et al. 2004; Yang et al. 2001). However, the $m p k 4$ and the $e d r l$ mutants in Arabidopsis showed increased resistance to virulent pathogens, revealing that the MAPK AtMPK4 and the MAPKKK EDR1 downregulate SA-dependent defense responses (Frye et al. 2001; Petersen et al. 2000).

The implication of MAPKs or of their upstream activators in the HR has been studied either by VIGS of the corresponding genes or by overexpressing constitutively active or inactive PKs. In tobacco, overexpression of NtMEK2, the MAPKK upstream of SIPK and WIPK, induces leaf necrosis (Yang et al. 2001). Random cDNA screening using VIGS in N. benthamiana $(\mathrm{Nb})$ plants was conducted in order to characterize plants impaired in Pto-mediated cell death; it was shown that silencing the NbMAPKKK $\alpha$ gene and the Lycopersicum esculentum (Le) LeMAPKKK $\alpha$ ortholog gene affected cell death (del Pozo et al. 2004). LeMAPKKK $\alpha$ is upstream of MEK2, and the pathway leading to the HR requires SIPK and the MAPK Ntf6, but not WIPK. In a VIGS candidate gene approach performed on tomato, Ekengren and associates (2003) identified MEK1/2 and Ntf6/WIPK but not SIPK as being involved in Pto resistance. In $N$. benthamiana, silencing WIPK and SIPK had no effect on the HR mediated by the INF1 elicitin produced by Phytophthora infestans (Sharma et al. 2003). Treating tobacco plants with the Pseudomonas syringae pv. phaseolicola-secreted harpin elicitor (HrpZ) induced HR, which is decreased in plants overexpressing SIPK and increased in plants silenced for SIPK by RNA interference (Samuel et al. 2005). Taken together, these contradictory results suggest that MAPK cascades are not the sole signal transduction pathway for cell death and highlight the complexity of the MAPK pathway. This complexity is further illustrated by results showing 
that suppressing SIPK by RNA interference is compensated by WIPK overaccumulation; conversely, overexpressing SIPK suppresses WIPK accumulation (Samuel and Ellis 2002).

$P K$ substrates and protein phosphorylation. A few MAPK substrates have been identified. Rice MAPK BWMK1 phosphorylates OsEREBP1, a transcription factor that regulates PR genes containing GCC box elements and, thereby, increases PR gene expression (Cheong et al. 2003). WIPK phosphorylates $N$. tabacum WIPK interacting factor (NtWIF), a novel transcription factor that contains a conserved B3-type DNA binding domain with high similarity to those of Arabidopsis auxin response factor (Yap et al. 2005). Recently, Katou and associates (2005) identified a protein named PPS3, which contains a ZIM motif found in a variety of plant transcription factors. PPS3 is phosphorylated by the Solanum tuberosum StMPK1, a MAPK with strong similarities with tobacco SIPK. Silencing the $N$. benthamiana PPS3 gene delayed the HR induced by the Phytophthora infestans hyphal wall component elicitor (Katou et al. 2005). Transcription factors of the WRKY family are also downstream of MAPK modules (Asai et al. 2002; Kim and Zhang 2004) and it was shown recently that SIPK phosphorylated WRKY1 (Menke et al. 2005). Some proteins may be required to couple MAPK and WRKY transcription factors. Indeed, MKS1 was identified by yeast two-hybrid screening as a substrate for Arabidopsis MPK4; MKS1 is phosphorylated by MPK4 in vitro and interacts with WRKY25 and WRKY33 in a two-hybrid screen (Andreasson et al. 2005). Substrates for Arabidopsis MPK6, the SIPK ortholog, have also been identified; they correspond to ACS2 and ACS6, two isoforms of 1-aminocyclopropane-1-carboxylic acid synthase (ACS) (Liu and Zhang 2004). ACSs are the rate-limiting enzymes of ethylene synthesis and are stabilized by phosphorylation. Considering the role played by ethylene in many aspects of plant life, including stress responses, this result appears to be of prime importance.

Studies of protein phosphorylation status have been performed by two-dimensional gel electrophoresis analysis of in vivo-labeled proteins extracted from cultivated cells treated with different elicitors (Droillard et al. 1997; LecourieuxOuaked et al. 2000; Nühse et al. 2003; Peck et al. 2001). The currently identified phosphorylated proteins are i) a tobacco calreticulin-like protein involved in calcium storage, which is dephosphorylated after treatment of cells with oligogalacturonides (Droillard et al. 1997); ii) Arabidopsis AtPhos43, which has two ankyrin-motifs usually involved in protein-protein interactions and is phosphorylated after treating the cells with flagellin or chitin fragments (Peck et al. 2001); and iii) syntaxin, an Arabidopsis-intrinsic membrane protein in which phosphorylation in response to flagellin is calcium-dependent and might be involved in membrane fusion and exocytosis (Nühse et al. 2003). The development of phosphoproteomics associated with mass spectrometry should rapidly increase the number of identified phosphorylated proteins and provide databases for phosphorylation sites (Nühse et al. 2004).

\section{Ion fluxes in plant defense.}

Role of calcium. Calcium is one of the most important second messengers in plants. It conveys signals received at the cell surface to the inside of the cell through spatiotemporal changes in cytosolic free calcium concentrations $\left(\left[\mathrm{Ca}^{2+}\right]_{\text {cyt }}\right)$ that are decoded by an array of " $\mathrm{Ca}^{2+}$ sensors" (Hetherington and Brownlee 2004; Sanders et al. 2002). How this $\mathrm{Ca}^{2+}$ signaling links different signals to so many diverse and specific responses remains unclear. The hypothesis that a $\mathrm{Ca}^{2+}$ response could be a point at which signal specificity might be encoded has recently been debated. The " $\mathrm{Ca}^{2+}$ signature" concept suggests that the $\mathrm{Ca}^{2+}$ specificity is due to the time course of
$\left[\mathrm{Ca}^{2+}\right]_{\text {cyt }}$ variations, together with the location of the $\left[\mathrm{Ca}^{2+}\right]_{\text {cyt }}$ increase (Hetherington and Brownlee 2004). Another possibility is that $\mathrm{Ca}^{2+}$ signals act as simple on-off binary switches (Plieth 2005; Scrase-Field and Knight 2003). The role of $\mathrm{Ca}^{2+}$ in plant defense signaling is now firmly established. Increased radioactive $\mathrm{Ca}^{2+}$ uptake from the apoplast was reported in plant cells treated with different elicitors, whereas various defense signaling events were prevented when calcium influx was compromised (Nürnberger et al. 1994; Stäb and Ebel 1987; Tavernier et al. 1995).

Methods for in vivo $\left[\mathrm{Ca}^{2+}\right]$ monitoring and imaging allowed the description of various pathogen- or elicitor-induced changes in $\left[\mathrm{Ca}^{2+}\right]_{\text {cyt }}$. The jellyfish aequorin is a $\mathrm{Ca}^{2+}$-binding photoprotein (Mithöfer and Mazars 2002), and aequorin-transformed plant cells have been used to determinate and compare specific $\left[\mathrm{Ca}^{2+}\right]_{\text {cyt }}$ fingerprints in different plant cell-elicitor systems. Using this technology, transient elevations in $\left[\mathrm{Ca}^{2+}\right]_{\text {cyt }}$ mainly have been reported as signal transduction responses to elicitor treatment. Interestingly, each elicitor triggers specific $\left[\mathrm{Ca}^{2+}\right]_{\mathrm{cyt}}$ elevations giving typical calcium signatures that differ in kinetics as well as in peak intensities. For example, cryptogein first triggered a transient and rapid $\left[\mathrm{Ca}^{2+}\right]_{\text {cyt }}$ increase which is followed immediately by a second and sustained $\left[\mathrm{Ca}^{2+}\right]_{\mathrm{cyt}}$ increase. The second $\left[\mathrm{Ca}^{2+}\right]_{\text {cyt }}$ elevation is believed to be part of the signaling pathway leading to sustained MAPK activation and the HR (Fig. 1) (Lecourieux et al. 2002).

Pharmacological data indicate that apoplastic $\mathrm{Ca}^{2+}$ is the main supplier for pathogen-induced $\left[\mathrm{Ca}^{2+}\right]_{\text {cyt }}$ variations. Supporting these findings, analyses have highlighted the involvement of $\mathrm{Ca}^{2+}$-permeable channels located on the plasma membrane in early defense signaling in tomato, parsley, and tobacco (Gelli et al. 1997; Kadota et al. 2004; Zimmermann et al. 1997). Furthermore, genetic analysis of the Arabidopsis mutants $h l m l$ and $d n d l$ impaired in their ability to produce HR in response to avirulent pathogens allowed the identification of cyclic nucleotide-gated ion channel (CNGC)-encoding genes. The lack of function of the corresponding genes is responsible for the lesion-mimic phenotype of the hlml mutant plant and the dwarf and loss-of-HR phenotype of the $d$ nd 1 mutant plant (Balagué et al. 2003; Clough et al. 2000). However, it has not yet been demonstrated in planta that these putative channels are located on the plasma membrane and are permeable to $\mathrm{Ca}^{2+}$. Changes in $\left[\mathrm{Ca}^{2+}\right]_{\text {cyt }}$ are also amplified by $\mathrm{H}_{2} \mathrm{O}_{2}$ generated during the elicitation process (Klüsener et al. 2002; Lecourieux et al. 2002).

Several studies also pointed out the potential contribution of $\mathrm{Ca}^{2+}$ release from internal stores, probably the vacuole and the endoplasmic reticulum that both usually are described as internal $\mathrm{Ca}^{2+}$ sources or buffering compartments for $\left[\mathrm{Ca}^{2+}\right]_{\text {cyt }}$ regulation (White and Broadley 2003). Indeed, the $\left[\mathrm{Ca}^{2+}\right]_{\text {cyt }}$ increase induced by several elicitors, including Pep-13, cryptogein, and BcPG1, was significantly reduced when ryanodine receptors (RYR) and inositol tri-phosphate receptors $\left(\mathrm{IP}_{3}-\mathrm{R}\right)$, two plant intracellular $\mathrm{Ca}^{2+}$ channels (Allen et al. 1995), were inhibited (Blume et al. 2000; Lamotte et al. 2004; Lecourieux et al. 2002; Vandelle et al. 2006). It has been proposed that these channels are regulated through a complex network of second messengers, including the RYR modulator cyclic ADP ribose (cADPR), cGMP, $\mathrm{IP}_{3}$, and NO (see below). However, except for NO, proof linking these signaling molecules to plant defense is still missing.

Of relevant interest is the physiological significance of changes in free calcium in organelles like chloroplasts, mitochondria, and nuclei. For instance, using the aequorin technology, different nuclear and cytoplasmic calcium signatures, correlated with the increase of $\mathrm{CaM}$ isoform NtCaM-1 gene expression, were observed depending on wind stimuli or cold 
shock in $N$. plumbaginifolia seedlings (van der Luit et al. 1999). A recent report indicated that isolated nuclei, in response to mechanical stimuli depending on the $\mathrm{pH}$ and temperature, showed an elevation of free nuclear calcium concentration (Xiong et al. 2004). Furthermore, we have recently reported specific changes in free nuclear calcium concentration $\left(\left[\mathrm{Ca}^{2+}\right]_{\text {nuc }}\right)$ in tobacco cells after treatment with various elicitors (Lecourieux et al. 2005). The physiological significance of these elicitor-induced $\left[\mathrm{Ca}^{2+}\right]_{\text {nuc }}$ rises remains to be determined. One expects nuclear calcium to be responsible for the activation of $\mathrm{Ca}^{2+}$-dependent proteins located in the nucleus and involved in the regulation of nuclear activities such as gene expression. Recently, Levy and associates (2005) identified an Arabidopsis gene, IQD1 (ID-DOMAIN 1), which encodes a nuclear protein that binds to $\mathrm{CaM}$ in a $\mathrm{Ca}^{2+}$-dependent fashion. Interestingly, IQD1 positively regulates accumulation of glucosinolates, which are secondary metabolites involved in resistance to generalist chewing and phloem-feeding insects. Taken as a whole, a specific cellular calcium signature resulting from the combination of organelles and cytosolic calcium variations appears to be involved in both biotic and abiotic stresses.

Changes in $\left[\mathrm{Ca}^{2+}\right]_{\text {cyt }}$ are deciphered by different types of $\mathrm{Ca}^{2+}$-sensors, including $\mathrm{CaMs}$, calcineurin $\mathrm{B}$-like proteins (CBLs), and $\mathrm{Ca}^{2+}$-regulated PKs. These $\mathrm{Ca}^{2+}$-binding proteins contain helix-loop-helix motifs called EF-hand domains that bind $\mathrm{Ca}^{2+}$ with high affinity (Reddy and Reddy 2004). In turn, these $\mathrm{Ca}^{2+}$ sensors can regulate the activity or function of a large number of target proteins (approximately 200 putative targets in Arabidopsis) or directly regulate gene expression (Bouché et al. 2005; Reddy and Reddy 2004). Most intracellular target proteins that sense and relay $\mathrm{Ca}^{2+}$ signatures toward the appropriate defense responses remain to be identified.

CaMs are ubiquitous $\mathrm{Ca}^{2+}$ receptors that transmit $\mathrm{Ca}^{2+}$ signals by interacting with a number of target proteins (Bouché et al. 2005). A number of studies have shown the involvement of plant CaMs during defense responses. Levels of individual $\mathrm{CaM}$ proteins are differentially regulated both transcriptionally and post-transcriptionally in plants upon exposure to pathogen infection. For instance, differential expression of specific CaM isoforms has been reported in soybean and tobacco cells challenged with fungal pathogens and Tobacco mosaic virus (TMV), respectively (Heo et al. 1999; Yamakawa et al. 2001). Transgenic tobacco plants over-expressing divergent CaM isoforms (SCaM-4 or SCaM-5) showed spontaneous lesions, constitutive expression of SAR-associated genes, and exhibited enhanced resistance to a wide spectrum of pathogens (Heo et al. 1999). The molecular targets of CaMs involved in defense response induction are still poorly known. They include i) a NAD kinase thought to modulate AOS production; ii) a glutamate decarboxylase which catalyzes the conversion of glutamate to GABA, a potential chemical deterrent against herbivores; iii) the cyclic nucleotide-gated channels DND1 and HLM1 mentioned above; iv) a tobacco MAPK phosphatase, NtMKP1, which negatively regulates defense-related MAPKs; v) a seven-transmembrane receptor-like protein referred to as MLO whose disruption confers broad-spectrum resistance to barley against powdery mildew disease; and vi) AtNOS1, an Arabidopsis nitric oxide synthase responsible for nitric oxide production (Bouché et al. 2005). The CDPKs, one of the largest families of potential $\mathrm{Ca}^{2+}$ sensors in plants, also are implicated in plant defense reactions (see above). In addition to $\mathrm{CaMs}$ and CDPKs, some other $\mathrm{Ca}^{2+}$-regulated proteins have been described as involved in pathogen-mediated defense responses. Respiratory burst oxidase homolog (Rboh) proteins responsible for the pathogen-induced oxidative burst contain 2 EF-hand domains, and a tobacco Rboh enzyme, can be stimulated directly by $\mathrm{Ca}^{2+}$ in vitro (Keller et al. 1998; Sagi and
Fluhr 2001). Centrins are CaM-like proteins with four EFhand motifs shown to be associated with the cytoskeleton. Expression of centrin genes is stimulated in various plant-pathogen systems (Cordeiro et al. 1998; Jakobek et al. 1999; Takezawa 2000). Due to the role of centrins in microtubule severing and cytoskeleton reorganization, one can expect that centrins perform a function related to intracellular reorganization during early infection. Indeed, several reports showed a rapid depolymerization of the microtubular network upon pathogen infection (Gross et al. 1993; Kobayashi et al. 1997) occurring in a $\mathrm{Ca}^{2+}$-dependent manner (Fig. 1) (Binet et al. 2001). Many EF-hand-less proteins bind $\mathrm{Ca}^{2+}$ via other motifs, such as the C2 domain (Reddy and Reddy 2004). The C2 domain mediates $\mathrm{Ca}^{2+}$-dependent interactions of proteins with membranes or membrane lipids. Up to now, two plant proteins that contain a C2 domain, namely copine and phospholipase D, have been associated with defense responses (Jambunathan and McNellis 2003; Jambunathan et al. 2001; Laxalt and Munnik 2002).

Role of anion effluxes. Anion effluxes are among the earliest signaling events detectable in elicitor-treated cells. For instance, in parsley, soybean, and tobacco cultured cells, enhanced $\mathrm{Cl}^{-}$ effluxes have been measured within 5 min of elicitor addition (Ebel et al. 1995; Jabs et al. 1997; Pugin et al. 1997). Furthermore, treating tobacco cells with cryptogein promotes a fast and important $\mathrm{NO}_{3}{ }^{-}$efflux that represents a drop in intracellular $\mathrm{NO}_{3}^{-}$of approximately $60 \%$ within $1 \mathrm{~h}$ (Wendehenne et al. 2002). Pharmacological approaches indicate that these anion channels play a critical role in the mediation of pathogen- and elicitor-induced events, including the oxidative burst, MAPK activation, and the transcriptional activation of defense genes (Jabs et al. 1997; Ligterink et al. 1997; Wendehenne et al. 2002). Furthermore, these data provide key evidence that anion channel activities are an early prerequisite for the HR. Indeed, anion channel blockers cause a significant inhibition of HR and cell death development in tobacco and soybean leaves and cell suspensions treated with cryptogein and Pseudomonas syringae pv. glycinea, respectively (Levine et al. 1996; Wendehenne et al. 2002). The nature of the link between anion effluxes and the HR is unresolved at present, but it probably involves $\mathrm{Ca}^{2+}$, which is a central second messenger in the plant machinery leading to cell death. Indeed, one function of plant anion channels might be to initiate or amplify plasma membrane depolarization (Fig. 1) which, in turn, activates voltage-dependent $\mathrm{Ca}^{2+}$ channels, leading to a rise in free $\left[\mathrm{Ca}^{2+}\right]_{\text {cyt }}$ (Ward et al. 1995). Furthermore, anion efflux-induced plasma membrane depolarization might activate $\mathrm{K}^{+}$efflux channels, $\mathrm{K}^{+}$release going together with water loss. This process might contribute to the shrinkage of the cells commonly observed during the HR. In plants, the decrease in water potential observed in incompatible interactions leading to $\mathrm{HR}$ is one factor restricting microbial growth (Wright and Beattie 2004). Similarly, in numerous apoptotic mammalian cell types, many studies favor the hypothesis that the decrease in cell volume, or more specifically the effluxes of $\mathrm{K}^{+}$and anions associated with the change in cell size, play a critical role in the regulation of the cell death machinery. More particularly, it has been shown that the decrease of intracellular $\mathrm{K}^{+}$concentration increases caspase activation and results in optimal catalytic activity of apoptotic nucleases (Hughes et al. 1997). It is interesting to note that, contrary to the model discussed above, $\mathrm{HrpN}_{\mathrm{ea}}$, the harpin secreted by the bacterial pathogen Erwinia amylovora, causes a fast decrease in anion current in Arabidopsis-cultured cells (El-Maarouf et al. 2001). Interestingly, $\mathrm{HrpN}_{\mathrm{ea}}$-induced cell death can be mimicked or counteracted by inhibitors or activators of cystic fibrosis transmembrane regulator (CFTR) $\mathrm{Cl}^{-}$ channels, respectively, suggesting that a decrease of CFTR- 
mediated anion current might be a necessary step of $\mathrm{HrpN}_{\mathrm{ea}}$ triggered cell death (Reboutier et al. 2005). Therefore, the mechanisms through which anion channels contribute to cell death might differ according to elicitors.

In mammals, members of the voltage-dependent gated anion channels (VDACs, or porins) are involved in the release of ions and cytochrome c during apoptosis. In plants, putative VDACs have been isolated via homology-based strategies and proteomic approaches based on mass spectrometry analyses of a plasma membrane fraction enriched in hydrophobic proteins (Marmagne et al. 2004; Wandrey et al. 2004). Targeting experiments demonstrated their presence in the mitochondria and plasma membranes. However, evidence that these proteins function as anion channels in native plant membranes is still lacking. Lacomme and Roby (1999) reported that a gene encoding a putative VDAC undergoes early induction in Arabidopsis cells treated with an HR-inducing strain of the pathogen Xanthomonas campestris pv. campestris. This exciting result suggests that this VDAC is a putative candidate for causing elicitor-induced large anion effluxes. In addition to VDACs, genes encoding putative voltage-dependent chloride channels (CLCs) have been identified in various plant species (BarbierBrygoo et al. 2000). The Arabidopsis mutant clca-1, in which the gene $A t C L C$-a has been disrupted, revealed an altered $\mathrm{NO}_{3}{ }^{-}$ content (Geelen et al. 2000). This raises the possibility that plant CLCs might function as $\mathrm{NO}_{3}{ }^{-}$plasma-membrane-permeable channels. However, the first immunolocalization experiments carried out establish that plant CLCs are not located in the plasma membrane but in the mitochondrial membrane (Lurin et al. 2000). Therefore, whether CLCs are involved in the modification of elicitor-triggered changes in plasma membrane permeability remains to be fully demonstrated.

What are the future directions then? The identification of $\mathrm{Ca}^{2+}$ and anions channels, the detailed description of their electrophysiological properties, and the generation of both defective and overexpressing ion channel mutants should shed light on the still enigmatic signaling role of ion fluxes in plant defense. Probably, one key function of ion channels is to initiate or propagate plasma membrane potential changes. Indeed, in addition to voltage-dependent channels, many transmembrane- or membrane-associated proteins, including signal transduction proteins, might undergo electrically dependent conformational changes. Such changes might modulate protein activities by exposing specific domains to PKs, protein phosphatases, or second messengers, including AOS and NO. Furthermore, electrical changes might modify protein-protein interactions and the ionic interaction between plasma membrane components and cytosolic proteins. Therefore, modifications of plasma membrane potential can be responsible for subtle changes of protein activities and should allow signal integration.

\section{NO signaling in plant defense.}

In the past 20 years, it has been shown that, in animal cells, the highly diffusible gas NO functions as a signaling molecule in a number of physiological processes, such as neurotransmitter release. Furthermore, under particular pathological conditions, NO has been found to be responsible for the killing of microorganisms and tumor cells by macrophages (Beck et al. 1999). NO synthesis is catalyzed by the CaM-dependent hemoprotein nitric oxide synthases (NOS) which oxidize L-arginine to NO and L-citrulline (Wendehenne et al. 2001). Once produced, NO operates through post-translational modifications and specifically targets cystein residues (S-nitrosylation), tyrosine residues (nitration), and heme or nonheme iron and copper centers (metal nitrosation) of a broad spectrum of proteins (Stamler et al. 2001). The interaction of NO with hemecontaining proteins is exemplified by the binding of $\mathrm{NO}$ to soluble guanylate cyclase which activates the enzyme and, therefore, increases the cGMP concentrations.

In plants, the enzymes responsible for NO synthesis include nitrate reductase (NR) and AtNOS1 from Arabidopsis thaliana (Guo et al. 2003; Yamasaki and Sakihama 2000). AtNOS1 belongs to a group of evolutionarily conserved CaM-dependent enzymes catalyzing NOS-like activity but lacking sequence homology with mammalian NOS. The Atnos 1 mutant impaired in Atnos 1 expression shows reduced organ growth and fertility as well as impaired ABA-induced stomatal closure. Furthermore, Guo and Crawford (2005) identified the cellular localization of AtNOS1 in the mitochondria and provided evidence that the enzyme protects the plant from dark-induced senescence by decreasing AOS accumulation and limiting protein and lipid oxidation. Taken together, these data indicate that NO fulfils a broad spectrum of functions in plant physiological processes.

Pharmacological, biochemical, and, more recently, genetic approaches provide evidence that NO also is produced endogenously in plant cells challenged by avirulent pathogens and elicitors (Delledonne 2005; Wendehenne et al. 2004). In tobacco cell suspensions and leaf tissues, treatment with cryptogein results in a rapid and transient increase of NO production (Fig. 1) (Foissner et al. 2000; Lamotte et al. 2004). Using the NOsensitive fluorophore 4,5 diaminofluoresceine, it has been shown that the cryptogein-induced NO production was first restricted to the plastids and then also was found in the nucleus, along the plasma membrane, and in the cytoplasm, suggesting that NO production happens in several cellular compartments or diffuses from the plastids. The identity of the enzyme catalyzing NO synthesis in response to cryptogein is currently unknown. However, although a mitochondrial localization of the cryptogein-induced source has not been observed (Foissner et al. 2000), the finding that the cryptogein-induced NO production is reduced by 50 to $80 \%$ by mammalian NOS inhibitors which suppress AtNOS1 enzymatic activity (Guo et al. 2003) suggests that NO production in tobacco might be catalyzed by an AtNOS1 tobacco ortholog. Supporting this hypothesis, key evidence that AtNOS1 is an important component of plant defense recently has been provided by Zeidler and associates (2004). In addition to AtNOS1, the possibility that cryptogeininduced NO synthesis might be catalyzed by a distinct NOSlike protein should not be excluded. Indeed, evidence of other potential NOS-like enzymes in plants has been reported in several studies (Corpas et al. 2004).

Evidence has accumulated to suggest that NO is part of intracellular signaling cascades activated in plant cells in response to pathogens or elicitors. At the transcriptional level, microarray and cDNA-AFLP data obtained from NO donortreated Arabidopsis cells indicate that NO modulates the expression of several defense genes, including genes encoding PR proteins and proteins related to secondary metabolism (Parani et al. 2004; Polverari et al. 2003). Accordingly, a functional link between elicitor-induced NO production and defense gene expression has been reported in several studies (Delledonne et al. 1998; Lamotte et al. 2004; Zeidler et al. 2004). At the post-translational level, extracellular administration of NO has been demonstrated to promote S-nitrosylation of redox-related and metabolic proteins involved in plant defense, such as glutathione S-transferase and S-adenosylmethionine synthetase (Lindermayr et al. 2005). Furthermore, pharmacological experiments infer that cGMP and cADPR might mediate NO effects during plant defense. Indeed, both compounds have been shown to be required for the induction of $P A L$ or $P R-1$ genes by NO (Durner et al. 1998). Because these two second messengers activate $\mathrm{Ca}^{2+}$-permeable channels in both animal and plant cells, it is then a short step to the 
hypothesis that $\mathrm{NO}$ is one of the key messengers governing the control of free $\mathrm{Ca}^{2+}$ mobilization in plant defense. This aspect of NO action is supported by the finding that NO participates in the cryptogein-mediated increase of $\left[\mathrm{Ca}^{2+}\right]_{\mathrm{cyt}}$ by promoting $\mathrm{Ca}^{2+}$ release from intracellular stores pharmacologically related to RYRs (Fig. 1) (Lamotte et al. 2004). Similar data have been reported in grapevine cells elicited by BcPG1 (Vandelle et al. 2006). Furthermore, it has been reported that NO donors elicit a fast increase of $\left[\mathrm{Ca}^{2+}\right]_{\text {cyt }}$ in Vicia faba guard cells and $N$. plumbaginifolia cells (Garcia-Mata et al. 2003; Lamotte et al. 2004, 2006). This effect can be suppressed by RYR inhibitors and selective antagonists of cADPR, confirming that NO may activate a signal transduction cascade which activates RYR. In contrast, in a series of experiments based on NO donors and scavengers, Lecourieux and associates (2005) provide evidence that, in tobacco cells, NO might not contribute to the changes in $\left[\mathrm{Ca}^{2+}\right]_{\text {nuc }}$ occurring, for instance, in response to cryptogein.

In mammals, NO is established as a potent inducer of apoptosis (Beck et al. 1999). A predominant mechanism by which this occurs is through the reaction of $\mathrm{NO}$ with $\mathrm{O}_{2}{ }^{-}$to generate peroxynitrite $\left(\mathrm{ONOO}^{-}\right)$, a highly cytotoxic compound causing uncontrolled protein tyrosine nitration. In plants, evidence that NO participates in the induction of the HR has been provided by several studies that examine the effects of mammalian NOS inhibitors and NO scavengers on pathogen- or elicitor-induced cell death (Delledonne et al. 1998; Zhang et al. 2003). According to Delledonne and associates (2001), the NO-dependent $\mathrm{HR}$ is not mediated by $\mathrm{ONOO}^{-}$, but results from the combined activities of $\mathrm{NO}$ and $\mathrm{H}_{2} \mathrm{O}_{2}$, where $\mathrm{H}_{2} \mathrm{O}_{2}$ is formed by dismutation of $\mathrm{O}_{2}{ }^{-}$. In tobacco, pharmacological analyses have shown that NO is involved, at least partially, in the induction of cryptogein-triggered cell death (Lamotte et al. 2004). However, this study also reveals that NO regulates the elicitor-mediated cell death independently of $\mathrm{H}_{2} \mathrm{O}_{2}$ and $\mathrm{ONOO}^{-}$. Regardless of how NO might be linked to cryptogein-triggered cell death, the observation that NO induces mobilization of intracellular $\mathrm{Ca}^{2+}$ provides an attractive mechanism. Finally, it is noteworthy that, in addition to their synergistic action (Delledonne et al. 2001), $\mathrm{NO}$ and $\mathrm{H}_{2} \mathrm{O}_{2}$ might control each other's synthesis. For example, exogenously applied $\mathrm{H}_{2} \mathrm{O}_{2}$ has been found to trigger $\mathrm{NO}$ production in mung bean through a $\mathrm{Ca}^{2+}$ influx-dependent process (Lum et al. 2002). Furthermore, it recently has been reported that $\mathrm{NO}$ produced in response to $\mathrm{BcPG} 1$ is required for the activation of plasma membrane NADPH oxidase in grapevine cells (Vandelle et al. 2006).

\section{AOS and plant defense reactions.}

Defense reactions can include rapid and intense production of highly reactive and toxic oxygen species generated through the sequential one-electron reduction of oxygen $\left(\mathrm{O}_{2}\right)$. Under physiological conditions, the first reduction of $\mathrm{O}_{2}$ forms the superoxide anion $\left(\mathrm{O}_{2}{ }^{-}\right)$and hydroperoxyl radical $\left(\mathrm{HO}_{2}{ }^{\circ}\right)$, the second step forms hydrogen peroxide $\left(\mathrm{H}_{2} \mathrm{O}_{2}\right)$, and the third step produces the hydroxyl radical $\left(\mathrm{OH}^{\circ}\right)$ via the Fenton reaction in the presence of transition metals such as iron or copper (Mori and Schroeder 2004). $\mathrm{OH}^{\circ}$ and $\mathrm{O}_{2}{ }^{--}$possess very short half-lives (from nanosecond to microsecond, respectively). Uncharged $\mathrm{H}_{2} \mathrm{O}_{2}$ is more stable and can diffuse across membranes, whereas $\mathrm{OH}^{*}$ cannot migrate in solution and instead reacts locally, notably with molecular targets by modifying their structure or activity. $\mathrm{H}_{2} \mathrm{O}_{2}$ as well as $\mathrm{OH}^{*}$ can react with polyunsaturated lipids in membranes, forming lipid peroxides, which can lead to biological membrane destruction (Grant and Loake 2000). Because cells are unable to detoxify $\mathrm{OH}^{*}$, an excess of this molecule results in irreversible damage and cell death.

In a wide range of incompatible plant-pathogen interactions involving bacteria, fungi or viruses, a biphasic AOS production has been observed with a first phase peaking after $20 \mathrm{~min}$ and a second phase occurring 4 to $6 \mathrm{~h}$ later which has been correlated with plant resistance (Allan and Fluhr 1997; Baker and Orlandi 1995; Lamb and Dixon 1997). The AOS accumulation is finely tuned by a balance of scavenging and producing enzymes. In a recent review, Mittler and associates (2004) identified 152 proteins involved in AOS homeostasis, located in almost all subcellular compartments. Superoxide anions $\left(\mathrm{O}_{2}{ }^{--}\right)$ can be dismutated spontaneously into $\mathrm{H}_{2} \mathrm{O}_{2}$; however, this reaction can be greatly accelerated by the enzymatic action of superoxide dismutase. Then, hydrogen peroxide can be detoxified efficiently by the action of the AOS-scavenging enzyme catalase. $\mathrm{H}_{2} \mathrm{O}_{2}$ accumulation can also be prevented by ascorbate peroxidase or glutathione peroxidase. On the other hand, although AOS can be generated by various enzymatic activities in plants (Mittler et al. 2004), the AOS-producing enzyme identified as crucial for plant resistance is the plasma membrane NADPH oxidase. In the tobacco-cryptogein model, as in other plant-elicitor interactions (Fig. 1), AOS production is totally abolished by diphenylene iodonium (DPI), a well-known suicide inhibitor of the mammalian NADPH oxidase (Allan and Fluhr 1997; Pugin et al. 1997). The plant NADPH oxidases, also called Rbohs, catalyze the production of superoxide by the one-electron reduction of oxygen, using NADPH as an electron donor (Pugin et al. 1997). In cryptogein-treated tobacco cells, transcript accumulation of the NtRbohD isoform is correlated with $\mathrm{H}_{2} \mathrm{O}_{2}$ production. Conversely, silencing NtrbohD results in the absence of AOS production in elicitortreated cells (Simon-Plas et al. 2002). All the plant rboh genes identified so far, in rice (Groom et al. 1996), Arabidopsis (Desikan et al. 1998; Keller et al. 1998; Torres et al. 1998), tomato (Amicucci et al. 1999), and potato (Yoshioka et al. 2001), possess two EF-hand motifs and are closely related to the mammalian calcium-regulated NADPH oxidase (NOX5) which possesses four EF-hand motifs (Torres and Dangl 2005).

AOS production in cryptogein-challenged tobacco cells is totally abolished by calcium chelators or calcium surrogates $\left(\mathrm{La}^{3+}\right.$ and $\left.\mathrm{Gd}^{3+}\right)$ and by inhibitors of Ser/Thr PKs, indicating that calcium influx and protein phosphorylation act upstream of the AOS-producing enzyme NtRbohD (Fig. 1) (Lecourieux et al. 2002; Lecourieux-Ouaked et al. 2000; Simon-Plas et al. 2002; Tavernier et al. 1995). The NtRbohD protein was localized unambiguously to the plasma membrane in accordance with an extracellular production of superoxide anions (SimonPlas et al. 2002). Small G protein Rac translocation to the membrane after cell stimulation is a critical factor for the activation of the mammalian NADPH oxidase complex. A tobacco Rac homologue (NtRac5), located on the plasma membrane of tobacco cells, has been characterized as a negative regulator of NtRbohD (Morel et al. 2004). However, no direct interaction between the two proteins has been obtained in two-hybrid assays (Morel et al. 2004). Contrarily, OsRac1 acts as a positive regulator of AOS production in rice (Ono et al. 2001), suggesting distinct effects depending on the particular isoforms of Rac and Rboh proteins. Recently, OsRac1 has been shown to interact with cinnamoyl-CoA reductase (OsCCR1), a key enzyme involved in the biosynthesis of monolignols which are polymerized into lignin in the presence of peroxidase and $\mathrm{H}_{2} \mathrm{O}_{2}$ (Kawasaki et al. 2006).

Transcriptional upregulation of $r b o h$ genes has been reported in potato and Arabidopsis after various elicitor treatments (Desikan et al. 1998; Yoshioka et al. 2001). Similar studies with pathogen-challenged Arabidopsis or $N$. benthamiana have demonstrated that AtRbohD and AtRbohF or NbRbohA and $\mathrm{NbRbohB}$, respectively, participate in AOS production (Torres et al. 2002; Yoshioka et al. 2003). Data showed that AOS pro- 
duction and downstream effects are dependent on the Rboh isoforms. This suggested that the expression of rboh genes (10 rboh genes in the Arabidopsis genome) and the properties of the corresponding enzymes (subcellular localization, rate, substrate specificity, and affinity) are of importance in determining plant defense responses.

AOS first were thought to be general cell death effectors acting on plants or invaders, because the oxidative burst most often is correlated with the HR (Apel and Hirt 2004) and AOS bactericidal effects are well known (Mehdy 1994). Indeed, lowering catalase or ascorbate peroxidase activities by genesilencing strategies highlights the role of $\mathrm{H}_{2} \mathrm{O}_{2}$ in stopping pathogen spread (Dat et al. 2003; Mittler et al. 1999). In cryptogein-treated tobacco plants, $\mathrm{H}_{2} \mathrm{O}_{2}$ plays an essential role in the execution of plant cell death by provoking an AOS-mediated lipid peroxidation under light conditions (Montillet et al. 2005). However, under dark conditions, the cryptogeininduced cell death is $\mathrm{H}_{2} \mathrm{O}_{2}$ independent but correlates with a 9lipoxygenase (LOX)-dependent massive production of free fatty acid hydroperoxides (Montillet et al. 2005; Rustérucci et al. 1999). This active lipid peroxidation is sufficient to trigger plant HR, as demonstrated by using a 9-LOX antisense strategy (Rancé et al. 1998). Other studies indicated an absence of strict correlation between AOS production and cell death: for example, although AtRbohD is mostly responsible for $\mathrm{H}_{2} \mathrm{O}_{2}$ production compared with AtRbohF, plant cell death is more compromised in the AtrbohF mutant than in the AtrbohD mutant challenged by avirulent Pseudomonas syringae DC3000 expressing the AvrRpm1 elicitor (Torres et al. 2002).

AOS are also versatile signaling molecules that mediate gene responses to developmental cues as well as abiotic and biotic environmental stresses (Apel and Hirt 2004; Laloi et al. 2004). In signal transduction pathways induced by pathogens or elicitors, AOS participated in MAPK activation (see above), generation of $\mathrm{Ca}^{2+}$ variations (see above), and modifications of the cellular redox state; these last two events generally were monitored after $\mathrm{H}_{2} \mathrm{O}_{2}$ accumulation (Rentel and Knight 2004). In plants, the redox state regulates NPR1, an essential activator of SA-dependent defense responses. NPR1 accumulates in the cytosol as an inactive oligomer maintained by disulfide bridges; after elicitation, its reduction releases monomeric units that move to the nucleus and interact with the reduced TGA1 transcription factor which, in turn, activates the SAdependent defense gene expression (Després et al. 2003; Mou et al. 2003). Thus, the AOS signaling cascade initiates a global transcriptome shift to execute appropriate genetic programs. Arabidopsis cells treated with $\mathrm{H}_{2} \mathrm{O}_{2}$ showed changes in the expression profiles of 175 genes (out of 11,000 on the microarray). The AOS-induced genes encode antioxidant enzymes, proteins associated with defense or signaling functions such as kinases or transcription factors (Desikan et al. 2001b). Furthermore, microarray profiling experiments on catalase-silenced plants have highlighted a cluster of $\mathrm{H}_{2} \mathrm{O}_{2}$-responsive genes, outlining pathways that seem to be involved in cell death (Gechev and Hille 2005; Vandenabeele et al. 2003). In addition to the effect of AOS on gene expression, the oxidative burst also orchestrates plant defense responses by reinforcing plant cell walls via oxidative cross-linking of soluble proteins (Bradley et al. 1992; Brisson et al. 1994) and increasing lignification (Bruce and West 1989; Kawasaki et al. 2006). The way these defense processes are coordinated in time and space is thought to prevent the pathogen from spreading.

\section{Conclusion.}

Complementary approaches in cell biology, biochemistry, and genetics using cell suspensions and whole plants have permitted identification of numerous events and proteins or genes involved in the signaling cascades immediately downstream of elicitor perception. Much work is still to be done before getting a general overview of plant defense signaling, including perception of elicitors, because most of the elicitor binding sites have not been characterized at the molecular level. The signal propagation does not follow a simple linear pathway (e.g., Fig. 1, scheme for cryptogein-induced signaling events) but, instead, is amplified through a complex network with many branches, each being controlled by a combination of second messengers including free calcium, AOS, NO, cytosolic $\mathrm{pH}$ and membrane potential changes, cGMP, cADPR, SA, JA, ethylene, and probably metabolites of primary metabolism. Furthermore, the important changes in the pentose phosphate pathway and the Krebs cycle in the first minutes after elicitor perception (Pugin et al. 1997), together with the inhibition of sugar transporters and of mitochondrial activities (Bourque et al. 2002), are bound to influence cell behavior. However, the attribution of a defense function to a particular protein or gene or second messenger is a complex problem whatever the approach used. For instance, while triggering defense responses, elicitors also induce abiotic stresses. Indeed, it has very often been reported that, by changing ion fluxes, elicitors induce osmotic pressure changes and cell plasmolysis. Thus, by studying the defense responses triggered by elicitors, we monitored events and activated or inhibited proteins that are also part of other signaling pathways. Moreover, not only does crosstalk between abiotic and biotic stresses occur, but crosstalk between defense pathways and physiological pathways, including development and hormone signaling pathways, also occurs (Lam 2004; Lorrain et al. 2003). It also should be taken into account that the induction of a signaling pathway can trigger its own negative feedback. For instance, during HR, cells activate or repress proteins or genes involved in cell survival, and many genes identified by genetic approaches aimed at identifying genes involved in the HR are, in fact, negative regulators of cell death (Tronchet et al. 2001).

Another crucial element that conditions the specificity of the response is the distribution of second messengers and targeted proteins in time and space. For instance, the output response of $\mathrm{Ca}^{2+}$-dependent pathways relies upon the subcellular localization, lag time, duration, intensity, and frequency of the $[\mathrm{Ca}]_{\mathrm{cyt}}$ rise ("calcium signature"). Taking into account the low diffusion rate of calcium, calcium-responding proteins may be closely linked to calcium channels localized in both plasma membranes and calcium internal store membranes, thus building a complex molecular scaffold able to translate a particular signal. One indication for the requirement of localized molecular modules is provided by experiments in which calcium ionophores were used to mimic elicitor-induced calcium influx. Calcium ionophores, which deliver $\mathrm{Ca}^{2+}$ independently of cellular processes and might be randomly incorporated in membranes, are unable to trigger defense reactions (Tavernier et al. 1995). Signaling transduction steps relying on second messengers with short half-lives, such as AOS and NO, should be particularly dependent on second messenger spatiotemporal production. In addition, AOS and NO also can combine and act in conjunction with calcium. Thus, as suggested by different authors, the complexity of signal integration, together with the amount of data from different signaling pathways, in different plant species, and in a wide range of developmental conditions, requires computer communication systems and models for the representation and analysis of signal transduction networks (Genoud and Metraux 1999; Rzhetsky et al. 2000; Trevino Santa Cruz et al. 2005). Consequently, databases for plant signaling networks are emerging and will be useful to integrate at the cellular level the relationships between individual components that have been identified independently. 
Because plant diseases cause billions of dollars in harvest loss annually with severe consequences for humans, particularly in developing countries, a major research initiative lies in the use of disease-resistant plants or in inducing resistance. One of the most convenient and environmentally soundest ways of limiting plant disease consists of conventional resistance breeding programs using disease-resistant cultivars possessing $R$ genes. Additionally, pesticides make it possible to limit pathogen development and crop losses. However, the emergence of resistant pathogen strains, the demand for good quality food, and human health preservation compromise the use of pesticides. In Europe, vineyards, which cover approximately $1 \%$ of cultivated surfaces, use half of the chemicals spread on fields (copper included); that is, 120,000 tons per year. Different pesticides recently have been forbidden in Europe; for instance, arsenite, which was the sole efficient chemical against trunk diseases due to fungi, including Escaand Eutypa diseases. Therefore, activating defense responses by using elicitors should be an alternative method in order to replace or reduce chemical applications. Elicitors have been shown to be efficient when sprayed on leaves or added in the soil (Aziz et al. 2003; Gorlach et al. 1996; Moffat 2001). Some inducers of defense responses, such as $\beta$-aminobutyric acid (BABA), do not trigger any detectable effect by themselves but, instead, act through potentiation of defense (a mechanism called priming) when the plant is challenged by a pathogen (Hamiduzzaman et al. 2005). How these compounds potentiate the defense response is under investigation. Compared with common elicitors, these inducers have the advantage of reducing the physiological fitness cost. Another problem encountered is the ability of these compounds to penetrate the tissues. Depending on their chemical nature, hydrophilic character, and molecular mass, plant cuticles and cell walls may prevent them from reaching plasma membranes or internal targets. In these conditions, efficient adjuvants have to be identified to have a chance of protecting crops successfully. For proteinaceous elicitors, the expression of $A v r$ transgenes, under the control of plant promoters induced by a range of pathogens, in plants expressing the corresponding $R$ genes, should enhance broadspectrum resistance and could be a valuable strategy in the future (McDowell and Woffenden 2003). Another transgenic approach could consist of transiently suppressing the expression of genes which negatively regulate defense response pathways. Thus, studying elicitor-activated signaling pathways is continuing with the purpose of identifying signaling components that could be exploited in the future as switches to activate resistance in order to design efficient strategies to protect crops.

\section{ACKNOWLEDGMENTS}

The work in our laboratory has been supported by the Ministère de l'Education Nationale de l'Enseignement Supérieur et de la Recherche, the Institut National de la Recherche Agronomique, and the Conseil Général de Bourgogne. We would like to thank R. Ranjeva, J. Guern for critical readings and suggestions and A. Buchwalter for revising the English. We apologize to those colleagues whose work we were unable to review because of lack of space.

\section{LITERATURE CITED}

Allan, A. C., and Fluhr, R. 1997. Two distinct sources of elicited reactive oxygen species in tobacco epidermal cells. Plant Cell 9:1559-1572.

Allen, G. J., Muir, S. R., and Sanders, D. 1995. Release of $\mathrm{Ca}^{2+}$ from individual plant vacuoles by both $\mathrm{InsP}_{3}$ and cyclic ADP-ribose. Science 268:735-737.

Allwood, E. G., Davies, D. R., Gerrish, C., and Bolwell, G. P. 2002. Regulation of CDPKs, including identification of PAL kinase, in biotically stressed cells of French bean. Plant Mol. Biol. 49:533-544.

Amicucci, E., Gaschler, K., and Ward, J. M. 1999. NADPH oxidase genes from tomato (Lycopersicon esculentum) and curly-leaf pondweed (Potamogeton crispus). Plant Biol. 1:524-528.

Andreasson, E., Jenkins, T., Brodersen, P., Thorgrimsen, S., Petersen, N. H. T., Zhu, S., Qiu, J.-L., Micheelsen, P., Rocher, A., Petersen, M. Newman, A., Nielsen, H. B., Hirt, H., Somssich, I., Mattsson, O., and Mundy, J. 2005. The MAP kinase substrate MKS1 is a regulator of plant defense responses. EMBO (Eur. Mol. Biol. Organ.) J. 24:25792589.

Apel, K., and Hirt, H. 2004. Reactive oxygen species: Metabolism, oxidative stress, and signal transduction. Annu. Rev. Plant Biol. 55:373-399.

Asai, T., Tena, G., Plotnikova, J., Willmann, M. R., Chiu, W.-L., GomezGomez, L., Boller, T., Ausubel, F. M., and Sheen, J. 2002. MAP kinase signaling cascade in Arabidopsis innate immunity. Nature 415:977-983.

Aziz, A., Poinssot, B., Daire, X., Adrian, M., Bezier, A., Lambert, B., Joubert, J. M., and Pugin, A. 2003. Laminarin elicits defense responses in grapevine and induces protection against Botrytis cinerea and Plasmopara viticola. Mol. Plant-Microbe Interact. 16:1118-1128.

Baker, C. J., and Orlandi, E. W. 1995. Active oxygen in plant pathogenesis. Annu. Rev. Phytopathol. 33:299-321.

Balagué, C., Lin, B., Alcon, C., Flottes, G., Malmstrom, S., Kohler, C., Neuhaus, G., Pelletier, G., Gaymard, F., and Roby, D. 2003. HML1, an essential signaling component in the hypersensitive response, is a member of the cyclic nucleotide-gated ion channel family. Plant Cell 15:365379.

Barbier-Brygoo, H., Vinauger, M., Colcombet, J., Ephritikhine, G., Frachisse, J.-M., and Maurel, C. 2000. Anion channels in higher plants: Functional characterization, molecular structure and physiological role. Biochim. Biophys. Acta 1465:199-218.

Beck, K.-F., Eberhardt, W., Franck, S., Huwiler, A., Messmer, U. K., Mühl, H., and Pfeilschifter, J. 1999. Inducible NO synthase: Role in cellular signaling. J. Exp. Biol. 202:645-653.

Binet, M.-N., Humbert, C., Lecourieux, D., Vantard, M., and Pugin, A. 2001. Disruption of microtubular cytoskeleton induced by cryptogein, an elicitor of hypersensitive response in tobacco cells. Plant Physiol. 125:564-572.

Blume, B., Nürnberger, T., Nass, N., and Scheel, D. 2000. Receptor-mediated increase in cytoplasmic free calcium required for activation of pathogen defense in parsley. Plant Cell 12:1425-1440.

Bouché, N., Yellin, A., Snedden, W. A., and Fromm, H. 2005. Plant-specific calmodulin-binding proteins. Annu. Rev. Plant Biol. 56:435-466.

Bourque, S., Binet, M.-N., Ponchet, M., Pugin, A., and Lebrun-Garcia, A. 1999. Characterization of the cryptogein binding sites on plant plasma membranes. J. Biol. Chem. 274:34699-34705.

Bourque, S., Lemoine, R., Sequeira-Legrand, A., Fayolle, L., Delrot, S., and Pugin, A. 2002. The elicitor cryptogein blocks glucose transport in tobacco cells. Plant Physiol. 130:2177-2187.

Bradley, D. J., Kjellbom, P., and Lamb, C. J. 1992. Elicitor- and woundinduced oxidative cross-linking of a proline-rich plant cell wall protein: A novel, rapid defense response. Cell 70:21-30.

Brisson, L. F., Tenhaken, R., and Lamb, C. 1994. Function of oxidative cross-linking of cell wall structural proteins in plant disease resistance Plant Cell 6:1703-1712.

Bruce, R. J., and West, C. A. 1989. Elicitation of lignin biosynthesis and isoperoxydase activity by pectic fragments in suspension-cultures of castor bean. Plant Physiol. 91:889-897.

Brunner, F., Rosahl, S., Lee, J., Rudd, J. J., Geiler, C., Kauppinen, S., Rasmussen, G., Scheel, D., and Nürnberger, T. 2002. Pep-13, a plant defense-inducing pathogen-associated pattern from Phytophthora transglutaminases. EMBO (Eur. Mol. Biol. Organ.) J. 21:6681-6688.

Cheong, Y. H., Moon, B. C., Kim, J. K., Kim, C. Y., Kim, M. C., Kim, I. H., Park, C. Y., Kim, J. C., Park, B. O., Koo, S. C., Yoon, H. W., Chung, W. S., Lim, C. O., Lee, S. Y., and Cho, M. J. 2003. BWMK1, a rice mitogen-activated protein kinase, locates in the nucleus and mediates pathogenesis-related gene expression by activation of a transcription factor. Plant Physiol. 132:1961-1972.

Chico, J. M., Raices, M., Tellez-Inon, M. T., and Ulloa, R. M. 2002. A calcium-dependent protein kinase is systemically induced upon wounding in tomato plants. Plant Physiol. 128:256-270.

Clarke, A., Desikan, R., Hurst, R. D., Hancock, J. T., and Neill, S. J. 2000. NO way back: Nitric oxide and programmed cell death in Arabidopsis thaliana suspension cultures. Plant J. 24:667-677.

Clough, S. J., Fengler, K. A., Yu, I. C., Lippok, B., Smith, R. K., and Bent, A. F. 2000. The Arabidopsis dndl "defense, no death" gene encodes a mutated cyclic nucleotide-gated ion channel. Proc. Natl. Acad. Sci. U.S.A. 97:9323-9328.

Cordeiro, M. C., Piqueras, R., de Oliveira, D. E., and Castresana, C. 1998. Characterization of early induced genes in Arabidopsis thaliana responding to bacterial inoculation: Identification of centrin and of a novel protein with two regions related to kinase domains. FEBS (Fed. Eur. Biol. Soc.) Lett. 434:387-393. 
Corpas, F. J., Barroso, J. B., Carreras, A., Quiros, M., Leon, A. M., Romero-Puertas, M. C., Esteban, F. J., Valderrama, R., Palma, J. M., Sandalio, L. M., Gomez, M., and del Rio, L. A. 2004. Cellular and subcellular localization of endogenous nitric oxide in young and senescent pea plants. Plant Physiol. 136:2722-2733.

Dangl, J. L., and Jones, J. D. 2001. Plant pathogens and integrated defence responses to infection. Nature 411:826-833.

Dat, J. F., Pellinen, R., Beeckman, T., Van De Cote, B., Langebartels, C., Kangasjarvi, J., Inze, D., and Van Breusegem, F. 2003. Changes in hydrogen peroxide homeostasis trigger an active cell death process in tobacco. Plant J. 33:621-632.

Delledonne, M. 2005. NO news is good news for plants. Curr. Opin. Plant Biol. 8:390-396.

Delledonne, M., Xia, Y., Dixon, R. A., and Lamb, C. 1998. Nitric oxide functions as a signal in plant disease resistance. Nature 394:585-588.

Delledonne, M., Zeier, J., Marocco, A., and Lamb, C. 2001. Signal interactions between nitric oxide and reactive oxygen intermediates in the plant hypersensitive disease resistance response. Proc. Natl. Acad. Sci. U.S.A. 98:13454-13459.

del Pozo, O., Pedley, K. F., and Martin, G. B. 2004. MAPKKKalpha is a positive regulator of cell death associated with both plant immunity and disease. EMBO (Eur. Mol. Biol. Organ.) J. 23:3072-3082.

Desikan, R., Burnett, E. C., Hancock, J. T., and Neill, S. J. 1998. Harpin and hydrogen peroxide induce the expression of a homologue of gp91phox in Arabidopsis thaliana suspension cultures. J. Exp. Bot. 49:17671771.

Desikan, R., Hancock, J. T., Ichimura, K., Shinozaki, K., and Neill, S. J. 2001a. Harpin induces activation of the Arabidopsis mitogen-activated protein kinases AtMPK4 and AtMPK6. Plant Physiol. 126:1579-1587.

Desikan, R., Mackerness, S., Hancock, J. T., and Neill, S. J. 2001b. Regulation of the Arabidopsis transcriptome by oxidative stress. Plant Physiol. 127:159-172.

Després, C., Chubak, C., Rochon, A., Clark, R., Bethune, T., Desveaux, D., and Fobert, P. R. 2003. The Arabidopsis NPR1 disease resistance protein is a novel cofactor that confers redox regulation of DNA binding activity to the basic domain/leucine zipper transcription factor TGA1. Plant Cell 15:2181-2191.

D’Ovidio, R., Mattei, B., Roberti, S., and Bellincampi, D. 2004. Polygalacturonases, polygalacturonase-inhibiting proteins and pectic oligomers in plant-pathogen interactions. BBA-Proteins Proteom. 1696:237-244.

Droillard, M.-J., Güclü, J., Le Caer, J.-P., Mathieu, Y., Guern, J., and Laurière, C. 1997. Identification of calreticulin-like protein as one of the phosphoproteins modulated in response to oligogalacturonides in tobacco cells. Planta 202:341-348.

Durner, J., Wendehenne, D., and Klessig, D. F. 1998. Defense gene induction in tobacco by nitric oxide, cyclic GMP, and cyclic ADP-ribose. Proc. Natl. Acad. Sci. U.S.A. 95:10328-10333.

Ebel, J. 1998. Oligoglucoside elicitor-mediated activation of plant defense. BioEssays 20:569-576.

Ebel, J., Bhagwat, A. A., Cosio, E. G., Feger, M., Kissel, U., Mithöfer, A., and Waldmüller, T. 1995. Elicitor-binding proteins and signal transduction in the activation of a phytoalexin defense response. Can. J. Bot. 73:506-510.

Ekengren, S. K., Liu, Y., Schiff, M., Dinesh-Kumar, S. P., and Martin, G. B. 2003. Two MAPK cascades, NPR1, and TGA transcription factors play a role in Pto-mediated disease resistance in tomato. Plant J. 36:905-907.

El-Maarouf, H., Barny, M. A., Rona, J. P., and Bouteau, F. 2001. Harpin, a hypersensitive response elicitor from Erwinia amylovora, regulates ion channel activities in Arabidopsis thaliana suspension cells. FEBS (Fed. Eur. Biol. Soc.) Lett. 497:82-84.

Enkerli, J., Felix, G., and Boller, T. 1999. The enzymatic activity of fungal xylanase is not necessary for its elicitor activity. Plant Physiol. 121:391398

Flor, H. H. 1947. Inheritance of reaction to rust in flax. J. Agric. Res. 74:241-262.

Foissner, I., Wendehenne, D., Langebartels, C., and Durner, J. 2000. In vivo imaging of an elicitor-induced nitric oxide burst in tobacco. Plant J. 23:817-824.

Frye, C. A., Tang, D., and Innes, R. W. 2001. Negative regulation of defense responses in plants by a conserved MAPKK kinase. Proc. Natl. Acad. Sci. U.S.A. 98:373-378.

Garcia-Mata, C., Gay, R., Sokolovski, S., Hills, A., Lamattina, L., and Blatt, M. R. 2003. Nitric oxide regulates $\mathrm{K}^{+}$and $\mathrm{Cl}^{-}$channels in guard cells through a subset of abscisic acid-evoked signaling pathways. Proc. Natl. Acad. Sci. U.S.A. 100:11116-11121.

Gechev, T. S., and Hille, J. 2005. Hydrogen peroxide as a signal controlling plant programmed cell death. J. Cell Biol. 168:17-20.

Geelen, D., Lurin, C., Bouchez, D., Frachisse, J.-M., Lelievre, F., Courtial, B., Barbier-Brygoo, H., and Maurel, C. 2000. Disruption of putative an- ion channel gene AtCLC- $\alpha$ in Arabidopsis suggests a role in the regulation of nitrate content. Plant J. 21:259-267.

Gelli, A., Higgins, V. J., and Blumwald, E. 1997. Activation of plant plasma membrane $\mathrm{Ca}^{2+}$-permeable channels by race-specific fungal elicitors. Plant Physiol. 113:269-279.

Genoud, T., and Metraux, J. P. 1999. Crosstalk in plant cell signaling: Structure and function of the genetic network. Trends Plant Sci. 4:503-507.

Gomez-Gomez, L., and Boller, T. 2000. FLS2: An LRR receptor-like kinase involved in the perception of the bacterial elicitor flagellin in Arabidopsis. Mol. Cell 5:1003-1011.

Gorlach, J., Volrath, S., Knauf-Beiter, G., Hengy, G., Beckhove, U., Kogel, K. H., Oostendorp, M., Staub, T., Ward, E., Kessmann, H., and Ryals, J. 1996. Benzothiadiazole, a novel class of inducers of systemic acquired resistance, activates gene expression and disease resistance in wheat Plant Cell 8:629-643.

Grant, J. J., and Loake, G. J. 2000. Role of reactive oxygen intermediates and cognate redox signaling in disease resistance. Plant Physiol. 124:21-30.

Groom, O. J., Torres, M. A., Fordham-Skelton, P., Hammond-Kosak, K. E., Robinson, N. J., and Jones, J. D. G. 1996. RbohA, a rice homologue of the mammalian gp91phox respiratory burst oxidase gene. Plant $\mathrm{J}$. 10:515-522.

Gross, P., Julius, C., Schmelzer, E., and Hahlbrock, K. 1993. Translocation of cytoplasm and nucleus to fungal penetration sites is associated with depolymerization of microtubules and defence gene activation in infected, cultured parsley cells. EMBO (Eur. Mol. Biol. Organ.) J. 12:1735-1744.

Gu, Y.-Q., Yang, C., Thara, V. K., Zhou, J., and Martin, G. B. 2000. Pti4 is induced by ethylene and salicylic acid, and its product is phosphorylated by the Pto kinase. Plant Cell 12:771-785.

Guo, F.-Q., and Crawford, N. M. 2005. Arabidopsis nitric ocide synthase1 is targeted to mitochondria and protects against oxidative damage and dark-induced senescence. Plant Cell 17:3436-3450.

Guo, F.-Q., Okamoto, M., and Crawford, N. M. 2003. Identification of a plant nitric oxide synthase gene involved in hormonal signaling. Science 302:100-103.

Hamiduzzaman, M. M., Jakab, G., Barnavon, L., Neuhaus, J. M., and Mauch-Mani, B. 2005. $\beta$-Aminobutyric acid-induced resistance against downy mildew in grapevine acts through the potentiation of callose formation and jasmonic acid signaling. Mol. Plant-Microbe Interact. 18:819-829.

Heo, W. D., Lee, S. H., Kim, M. C., Kim, J. C., Chung, W. S., Chun, H. J., Lee, K. J., Park, C. Y., Park, H. C., Choi, J. Y., and Cho, M. J. 1999. Involvement of specific calmodulin isoforms in salicylic acid-independent activation of plant disease resistance responses Proc. Natl. Acad. Sci. U.S.A. $96: 766-771$

Hetherington, A. M., and Brownlee, C. 2004. The generation of $\mathrm{Ca}^{2+}$ signals in plants. Annu. Rev. Plant Biol. 55:401-427.

Hrabak, E. M., Chan, C. W. M., Gribskov, M., Harper, J. F., Choi, J. H., Halford, N., Kudla, J., Luan, S., Nimmo, H. G., Sussman, M. R., Thomas, M., Walker-Simmons, K., Zhu, J.-K., and Harmon, A. C. 2003. The Arabidopsis CDPK-SnRK superfamily of protein kinases. Plant Physiol. 132:660-680.

Hughes, F. M. J., Bortner, C. D., Purdy, G. D., and Cidlowski, J. A. 1997. Intracellular $\mathrm{K}^{+}$suppresses the activation of apoptosis in lymphocytes. J. Biol. Chem. 272:30567-30576.

Jabs, T., Tschöpe, M., Colling, C., Hahlbrock, K., and Scheel, D. 1997. Elicitor-stimulated ion fluxes and $\mathrm{O}_{2}^{-}$from the oxidative burst are essential components in triggering defense gene activation and phytoalexin synthesis in parsley. Proc. Natl. Acad. Sci. U.S.A. 94:4800-4805.

Jakobek, J. L., Smith-Becker, J. A., and Lindgren, P. B. 1999. A bean cDNA expressed during a hypersensitive reaction encodes a putative calcium-binding protein. Mol. Plant-Microbe Interact. 12:712-719.

Jambunathan, N., and McNellis, T. W. 2003. Regulation of Arabidopsis COPINE 1 gene expression in response to pathogens and abiotic stimuli. Plant Physiol. 132:1370-1381.

Jambunathan, N., Siani, J. M., and McNellis, T. W. 2001. A humidity-sensitive Arabidopsis copine mutant exhibits precocious cell death and increased disease resistance. Plant Cell 13:2225-2240.

Jia, Y., McAdams, S. A., Bryan, G. T., Hershey, H. P., and Valent, B. 2000. Direct interaction of resistance gene and avirulence gene products confers rice blast resistance. EMBO (Eur. Mol. Biol. Organ.) J. 19:40044014

Jin, H., Axtell, M. J., Dahlbeck, D., Ekwanna, O., Zhang, S., Staskawicz, B., and Baker, B. 2002. NPK1, an MEKK1-like mitogen-activated protein kinase kinase kinase, regulates innate immunity and development in plants. Dev. Cell 3:291-297.

Jin, H., Liu, Y., Yang, K.-Y., Kim, C. Y., Baker, B., and Zhang, S. 2003. Function of a mitogen-activated protein kinase pathway in $\mathrm{N}$-gene mediated resistance in tobacco. Plant J. 33:719-731. 
Jonak, C., Okrész, L., Bögre, L., and Hirt, H. 2002. Complexity, cross-talk and integration of plant MAP kinase signaling. Curr. Opin. Plant Biol. $5: 415-424$.

Joosten, M. H. A. J., and de Wit, P. J. G. M. 1999. The tomato Cladosporium fulvum interaction: A Versatile Experimental System to Study Plant-Pathogen Interactions. Annu. Rev. Phytopathol. 37:335-367.

Kadota, Y., Furuichi, T., Ogasawara, Y., Goh, T., Higashi, K., Muto, S., and Kuchitsu, K. 2004. Identification of putative voltage-dependent $\mathrm{Ca}^{2+}$ permeable channels involved in cryptogein-induced $\mathrm{Ca}^{2+}$ transients and defense responses in tobacco BY-2 cells. Biochem. Biophys. Res. Commun. 317:823-830.

Katou, S., Yoshioka, H., Kawakita, K., Rowland, O., Jones, J. D. G., Mori, H., and Doke, N. 2005. Involvement of PPS3 phosphorylated by elicitor-responsive mitogen-activated protein kinases in the regulation of plant cell death. Plant Physiol. 139:1914-1926.

Kawasaki, T., Koita, H., Nakatsubo, T., Hasegawa, K., Wakabayashi, K., Takahashi, H., Umemura, K., Umezawa, T., and Shimamoto, K. 2006. Cinnamoyl-CoA reductase, a key enzyme in lignin biosynthesis, is an effector of small GTPase Rac in defense signaling in rice. Proc. Natl. Acad. Sci. U.S.A. 103:230-235.

Keen, N. T., Partridge, J., and Zaki, A. I. 1972. Pathogen-produced elicitor of a chemical defense mechanism in soybeans monogenetically resistant to Phytophthora megasperma var. glycinea. (Abstr.) Phytopathology 62:768.

Keller, T., Damude, H. G., Werner, D., Doerner, P., Dixon, R. A., and Lamb, C. 1998. A plant homolog of the neutrophil NADPH oxidase gp $91^{\text {phox }}$ subunit gene encodes a plasma membrane protein with $\mathrm{Ca}^{2+}$ binding motifs. Plant Cell 10:255-266.

Kim, C.-Y., and Zhang, S. 2004. Activation of a mitogen-activated protein kinase cascade induces WRKY family of transcription factors and defense genes in tobacco. Plant J. 38:142-151.

Klüsener, B., Young, J. J., Murata, Y., Allen, G. J., Mori, I. C., Hugouvieux, V., and Schroeder, J. I. 2002. Convergence of calcium signaling pathways of pathogenic elicitors and abscisic acid in Arabidopsis guard cells. Plant Physiol. 130:2152-2163.

Kobayashi, Y., Kobayashi, I., Funaki, Y., Fujimoto, S., Takemoto, T., and Kunoh, H. 1997. Dynamic reorganization of microfilaments and microtubules is necessary for the expression of non-host resistance in barley coleoptile cells. Plant J. 11:525-537.

Kovtun, Y., Chiu, W.-L., Tena, G., and Sheen, J. 2000. Functional analysis of oxidative stress-activated mitogen activated protein kinase cascade in plants. Proc. Natl. Acad. Sci. U.S.A. 97:2940-2945.

Kumar, D., and Klessig, D. F. 2000. Differential induction of tobacco MAP kinases by the defense signals nitric oxide, salicylic acid, ethylene, and jasmonic acid. Mol. Plant-Microbe Interact. 13:347-351.

Kurusu, T., Yagala, T., Miyao, A., Hirochika, H., and Kuchitsu, K. 2005. Identification of a putative voltage-gated $\mathrm{Ca}^{2+}$ channel as a key regulator of elicitor-induced hypersensitive cell death and mitogen-activated protein kinase activation in rice; Plant J. 42:798-809.

Lacomme, C., and Roby, D. 1999. Identification of new early markers of the hypersensitive response in Arabidopsis thaliana. FEBS (Fed. Eur. Biol. Soc.) Lett. 459:149-153.

Laloi, C., Apel, K., and Danon, A. 2004. Reactive oxygen signaling: The latest news. Curr. Opin. Plant Biol. 7:323-328.

Lam, E. 2004. Controlled cell death, plant survival and development. Nat. Rev. Mol. Cell Biol. 5:305-315.

Lamb, C., and Dixon, R. 1997. The oxidative burst in plant disease resistance. Annu. Rev. Plant Physiol. Plant Mol. Biol. 48:251-275.

Lamotte, O., Gould, K., Lecourieux, D., Sequeira-Legrand, A., LebrunGarcia, A., Dürner, J., Pugin, A., and Wendehenne, D. 2004. Analysis of nitric oxide signaling functions in tobacco cells challenged by the elicitor cryptogein. Plant Physiol. 135:516-529.

Lamotte, O., Courtois, C., Dobrowolska, G., Besson, A., Pugin, A., and Wendehenne, D. 2006. Mechanisms of nitric oxide-induced increase of free cytosolic $\mathrm{Ca}^{2+}$ concentration in Nicotiana plumbaginifolia cells. Free Rad. Biol. Med. 40:1369-1376.

Laxalt, A. M., and Munnik, T. 2002. Phospholipid signaling in plant defence. Curr. Opin. Plant Biol. 5:332-338.

Lebrun-Garcia, A., Ouaked, F., Chiltz, A., and Pugin, A. 1998. Activation of MAPK homologues by elicitors in tobacco cells. Plant J. 15:773-781.

Lecourieux, D., Mazars, C., Pauly, N., Ranjeva, R., and Pugin, A. 2002. Analysis and effects of cytosolic free calcium elevations in response to elicitors in Nicotiana plumbaginifolia cells. Plant Cell 14:2627-2641.

Lecourieux, D., Lamotte, O., Bourque, S., Wendehenne, D., Mazars, C., Ranjeva, R., and Pugin, A. 2005. Proteinaceous and oligosaccharidic elicitors induce different calcium signatures in the nucleus of tobacco cells. Cell Calcium 38:527-538

Lecourieux-Ouaked, F., Pugin, A., and Lebrun-Garcia, A. 2000. Phosphoproteins involved in the signal transduction of cryptogein, an elicitor of defense reactions in tobacco. Mol. Plant-Microbe Interact. 13:821-829.
Lee, J., Klessig, D. F., and Nürnberger, T. 2001. A harpin binding site in tobacco plasma membranes mediates activation of the pathogenesis-related gene HIN1 independent of extracellular calcium but dependent on mitogen-activated protein kinase activity. Plant Cell 13:1079-1093.

Leister, R. T., and Katagiri, F. 2000. A resistance gene product of the nucleotide binding site-leucine rich repeats class can form a complex with bacterial avirulence proteins in vivo. Plant J. 22:345-354.

Levine, A., Pennell, R. I., Alvarez, M. E., Palmer, R., and Lamb, C. 1996. Calcium-mediated apoptosis in a plant hypersensitive disease resistance response. Curr. Biol. 6:427-437.

Levy, M., Wang, Q., Kaspi, R., Parrella, M. P., and Abel, S. 2005. Arabidopsis IQD1, a novel calmodulin-binding nuclear protein, stimulates glucosinolate accumulation and plant defense. Plant J. 43:79-96.

Ligterink, W., Kroj, T., zur Nieden, U., Hirt, H., and Scheel, D. 1997. Receptor-mediated activation of a MAP kinase in pathogen defense of plants. Science 276:2054-2057.

Lindermayr, C., Saalbach, G., and Durner, J. 2005. Proteomic identification of S-nitrosylated proteins in Arabidopsis. Plant Physiol. 137:921930 .

Link, V. L., Hofmann, M., Sinha, A. K., Ehness, R., Strnad, M., and Roitsch, T. 2002. Biochemical evidence for the activation of distinct subsets of mitogen-activated protein kinases by voltage and defenserelated stimuli. Plant Physiol. 128:271-281.

Liu, G.-Z., Pi, L.-Y., Walker, J. C., Ronald, P. C., and Song, W.-Y. 2002. Biochemical characterization of the kinase domain of the rice disease resistance receptor-like kinase XA21. J. Biol. Chem. 277:20264-20269.

Liu, Y., Schiff, M., and Dinesh-Kumar, S. P. 2004. Involvement of MEK1 MAPKK, NTF6 MAPK, WRKY/MYB transcription factors, COI1 and CTR1 in N-mediated resistance to tobacco mosaic virus. Plant J. 38:800-809.

Liu, Y., and Zhang, S. 2004. Phosphorylation of 1-aminocyclopropane-1carboxylic acid synthase by MPK6, a stress-responsive mitogen-activated protein kinase, induces ethylene biosynthesis in Arabidopsis. Plant Cell 16:3386-3399.

Lorrain, S., Vailleau, F., Balagué, C., and Roby, D. 2003. Lesion mimic mutants: Key for deciphering cell death and defense pathways in plants? Trends Plant Sci. 8:263-271.

Lum, H. K., Butt, Y. K., and Lo, S. C. 2002. Hydrogen peroxide induces a rapid production of nitric oxide in mung bean (Phaseolus aureus). Nitric Oxide 6:205-213.

Lurin, C., Guclu, J., Cheniclet, C., Carde, J. P., Barbier-Brygoo, H., and Maurel, C. 2000. CLC-Nt1, a putative chloride channel protein of tobacco, co-localizes with mitochondrial membrane markers. Biochem J. 348:291-295.

Marmagne, A., Rouet, M. A., Ferro, M., Rolland, N., Alcon, C., Joyard, J., Garin, J., Barbier-Brygoo, H., and Ephritikhine, G. 2004. Identification of new intrinsic proteins in Arabidopsis plasma membrane proteome. Mol. Cell Proteom. 3:675-691.

McDowell, J. M., and Woffenden, B. J. 2003. Plant disease resistance genes: Recent insights and potential applications. Trends Biotechnol. 21:178-183.

Mehdy, M. C. 1994. Active oxygen species in plant defense against pathogens. Plant Physiol. 105:467-472.

Menke, F. L. H., van Pelt, J. A., Pieterse, C. M. J., and Klessig, D. F. 2004 Silencing of the mitogen-activated protein kinase MPK6 compromises disease resistance in Arabidopsis. Plant Cell 16:897-809.

Menke, F. L. H., Kang, H.-G., Chen, Z., Mee Park, J., Kumar, D., and Klessig, D. F. 2005. Tobacco transcription factor WRKY1 is phosphorylated by the MAP kinase SIPK and mediates HR-like cell death in tobacco. Mol. Plant -Microbe Interact. 10:1027-1034.

Mithofer, A., and Mazars, C. 2002. Aequorin-based measurements of intracellular $\mathrm{Ca}^{2+}$-signatures in plant cells. Biol. Proc. Online 4:105118.

Mittler, R., Lam, E., Shulaev, V., and Cohen, M. 1999. Signals controlling the expression of cytosolic ascorbate peroxidase during pathogeninduced programmed cell death in tobacco. Plant Mol. Biol. 39:10251035.

Mittler, R., Vanderauwera, S., Gollery, M., and Van Breusegem, F. 2004. Reactive oxygen network of plants. Trends Plant Sci. 9:490-498.

Moffat, A. S. 2001. Plant biotechnology. For plants, reproduction without sex may be better. Science 294:2463-2465.

Montillet, J. L., Chamnongpol, S., Rustérucci, C., Dat, J., Van De Cotte, B. Agnel, J. P., Battesti, C., Inzé, D., Van Breusegem, F., and Trianphylidès, C. 2005. Fatty acid hydroperoxides and $\mathrm{H}_{2} \mathrm{O}_{2}$ in the execution of hypersensitive cell death in tobacco leaves. Plant Physiol. 138:15161526

Moon, H., Lee, B., Choi, G., Shin, D., Prasad, D. T., Lee, O., Kwak, S.-S., Kim, D. H., Nam, J., Hong, J. C., Lee, S. Y., Cho, M. J., Lim, C. O., and Yun, D.-J. 2003. NDP kinase 2 interacts with two oxidative stress-activated MAPKs to regulate cellular redox state and enhances multiple 
stress tolerance in transgenic plants. Proc. Natl. Acad. Sci. U.S.A 100:358-363.

Morel, J., Fromentin, J., Blein, J. P., Simon-Plas, F., and Elmayan, T. 2004. Rac regulation of NtrbohD, the oxidase responsible for the oxidative burst in elicited tobacco cell. Plant J. 37:282-293.

Mori, I. C., and Schroeder, J. I. 2004. Reactive oxygen species activation of plant $\mathrm{Ca}^{2+}$ channels. A signaling mechanism in polar growth, hormone transduction, stress signaling, and hypothetically mechanotransduction. Plant Physiol. 135:702-708.

Mou, Z., Fan, W. H., and Dong, X. N. 2003. Inducers of plant systemic acquired resistance regulate NPR1 function through redox changes. Cell 113:935-944.

Murillo, I., Jaeck, E., Cordero, M. J., and Secondo, B. S. 2001. Transcriptional activation of a maize calcium-dependent protein kinase gene in response to fungal elicitors and infection. Plant Mol. Biol. 45:145-158.

Nakagami, H., Kiegerl, S., and Hirt, H. 2004. OMTK1, a novel MAPKKK, channels oxidative stress signaling through direct MAPK activation. J. Biol. Chem. 279:26959-26966.

Nimchuk, Z., Eulgem, T., Holt, B. F., and Dangl, J. L. 2003. Recognitin and response in plant immune system. Annu. Rev. Genet. 37:579-609.

Nühse, T. S., Boller, T., and Peck, S. C. 2003. A plasma membrane syntaxin is phosphorylated in response to the bacterial elicitor flagellin. J. Biol. Chem. 278:45248-45254.

Nühse, T. S., Stenballe, A., Jensen, O. N., and Peck, S. C. 2004. Phosphoproteomics of the Arabidopsis plasma membrane and a new phosphorylation site database. Plant Cell 16:2394-2405.

Nürnberger, T., Nennstiel, D., Jabs, T., Sacks, W. R., Halhbrock, K., and Scheel, D. 1994. High affinity binding of a fungal oligopeptide elicitor to parsley plasma membranes triggers multiple defense responses. Cell 78:449-460

Nürnberger, T., Brunner, F., Kemmerling, B., and Piater, L. 2004. Innate immunity in plants and animals: Striking similarities and obvious differences. Immunol. Rev. 198:249-266.

Ono, E., Wong, H. L., Kawasaki, T., Hasegawa, M., Kodama, O., and Shimamoto, K. 2001. Essential role of the small GTPase Rac in disease resistance of rice. Proc. Natl. Acad. Sci. U.S.A. 98:759-764.

Parani, M., Rudrabhatla, S., Myers, R., Weirich, H., Smith, B., Leaman, D. W., and Goldman, S. L. 2004. Microarray analysis of nitric oxide responsive transcripts in Arabidopsis. Plant Biotechnol. J. 2:359-366.

Peck, S. C., Nuhse, T. S., Hess, D., Iglesias, A., Meins, F., and Boller, T. 2001. Directed proteomics identifies a plant-specific protein rapidly phosphorylated in response to bacterial and fungal elicitors Plant Cell 13:1467-1475.

Pedley, K. F., and Martin, G. B. 2004. Identification of MAPKs and their possible MAPKK activators involved in the Pto-mediated defense response of tomato. J. Biol. Chem. 279:49229-49235.

Petersen, M., Brodersen, P., Naested, H., Andreasson, E., Lindhart, U., Johansen, B., Nielsen, H. B., Lacy, M., Austin, M. J., Parker, J. E., Sharma, S. B., Klessig, D. F., Martienssen, R., Mattson, O., Jensen, A. B., and Mundy, J. 2000. Arabidopsis MAP kinase 4 negatively regulates systemic acquired resistance. Cell 103:1111-1120.

Plieth, C. 2005. Calcium: Just another regulator in the machinery of life? Ann. Bot. (Lond). 96:1-8.

Poinssot, B., Vandelle, E., Bentéjac, M., Adriain, M., Levis, C., Brygoo, Y., Garin, J., Scicilia, F., Coutos-Thévenot, P., and Pugin, A. 2003. The endopolygalacturonase 1 from Botrytis cinerea activates grapevine defence reactions unrelated to its enzymatic activity. Mol. Plant-Microbe Interact. 16:553-564.

Polverari, A., Molesini, B., Pezzotti, M., Buonaurio, R., Marte, M., and Delledonne, M. 2003. Nitric oxide-mediated transcriptional changes in Arabidopsis thaliana. Mol. Plant-Microbe Interact. 16:1094-1105.

Pugin, A., Frachisse, J.-M., Tavernier, E., Bligny, R., Gout, E., Douce, R. and Guern, J. 1997. Early events induced by the elicitor cryptogein in tobacco cells: Involvement of a plasma membrane NADPH oxidase and activation of glycolysis and the pentose phosphate pathway. Plant Cell 9:2077-2091

Rabea, E. I., Badawy, M. E.-T., Stevens, C. V., Smagghe, G., and Steurbaut, W. 2003. Chitosan as antimicrobial agent: Applications and mode of action. Biomacromolecules 4:1457-1465.

Rancé, I., Fournier, J., and Esquerré-Tugayé, M.-T. 1998. The incompatible interaction between Phytophthora parasitica var. nicotianae race 0 and tobacco is suppressed in transgenic plants expressing antisense lipoxygenase sequences. Proc. Natl. Acad. Sci. U.S.A. 95:6554-6559.

Reboutier, D., Frankart, C., Vedel, R., Brault, M., Duggleby, R. G., Rona, J. P., Barny, M. A., and Bouteau, F. 2005. A CFTR chloride channel activator prevents HrpNea-induced cell death in Arabidopsis thaliana suspension cells. Plant Physiol. Biochem. 43:567-572.

Reddy, V. S., and Reddy, A. S. 2004. Proteomics of calcium-signaling components in plants. Phytochemistry 65:1745-1776.

Ren, D., Yang, H., and Zhang, S. 2002. Cell death mediated by MAPK is associated with hydrogen peroxide production in Arabidopsis. J. Biol. Chem. 277:559-565.

Rentel, M. C., and Knight, M. R. 2004. Oxidative stress-induced calcium signaling in Arabidopsis. Plant Physiol. 135:1471-1479.

Rentel, M. C., Lecourieux, D., Ouaked, F., Usher, S. L., Petersen, L., Okamoto, H., Knight, H., Peck, S. C., Grierson, C. S., Hirt, H., and Knight, M. R. 2003. OXI1 kinase is necessary for oxidative burst-mediated signaling in Arabidopsis. Nature 427:858-861.

Reymond, P., and Farmer, E. E. 1998. Jasmonate and salicylate as global signals for defense gene expression. Curr. Opin. Plant Biol. 1:404-411.

Ricci, P. 1997. Induction of the hypersensitive response and systemic acquired resistance by fungal proteins: The case of elicitins. Pages 53-75 in: Plant-Microbe Interactions. Vol. 3. G. Stacey and N. T. Keen, eds. Chapman and Hall, New York.

Romeis, T., Piedras, P., Zhang, S. Q., Klessig, D. F., Hirt, H., and Jones, J. D. G. 1999. Rapid Avr9- and Cf-9-dependent activation of MAP kinases in tobacco cell cultures and leaves: Convergence of resistance gene, elicitor, wound, and salicylate responses. Plant Cell 11:273-287.

Romeis, T., Piedras, P., and Jones, J. D. G. 2000. Resistance gene-dependent activation of a calcium-dependent protein kinase in the plant defense response. Plant Cell 12:803-815.

Romeis, T., Ludwig, A. A., Martin, R., and Jones, J. D. G. 2001. Calciumdependent protein kinases play an essential role in a plant defence response. EMBO (Eur. Mol. Biol. Organ.) J. 20:5556-5567.

Rowland, O., Ludwig, A. A., Merrick, C. J., Baillieul, F., Tracy, F. E., Durrant, W. E., Fritz-Laylin, L., Nekrasov, V., Sjölander, K., Yoshioka, H., and Jones, J. D. G. 2005. Functional analysis of Avr9/Cf-9 rapidly elicited genes identifies a protein kinase, ACIK1, that is essential for full Cf-9dependent disease resistance in tomato. Plant Cell 17:295-310.

Rustérucci, C., Montillet, J. L., Agnel, J. P., Battesti, C., Alonso, B., Knoll, A., Bessoule, J. J., Etienne, P., Suty, L., Blein, J. P., and Triantaphylides, C. 1999. Involvement of lipoxygenase-dependent production of fatty acid hydroperoxides in the development of the hypersensitive cell death induced by cryptogein on tobacco leaves. J. Biol. Chem. 274:3644636455.

Rzhetsky, A., Koike, T., Kalachikov, S., Gomez, S. M., Krauthammer, M., Kaplan, S. H., Kra, P., Russo, J. J., and Friedman, C. 2000. A knowledge model for analysis and simulation of regulatory networks. Bioinformatics 16:1120-1128.

Sagi, M., and Fluhr, R. 2001. Superoxide production by plant homologues of the gp91(phox) NADPH oxidase. Modulation of activity by calcium and by Tobacco Mosaic Virus infection. Plant Physiol. 126:1281-1290.

Samuel, M. A., and Ellis, B. E. 2002. Double jeopardy: Both overexpression and suppression of a redox-activated plant mitogen-activated protein kinase render tobacco plants ozone sensitive. Plant Cell 14:20592069

Samuel, M. A., Hall, H., Krzymowska, M., Drzewiecka, K., Henning, J., and Ellis, B. E. 2005. SIPK signaling controls multiple components of harpin-induced cell death in tobacco. Plant J. 42:406-416.

Sanders, D., Pelloux, J., Brownlee, C., and Harper, J. F. 2002. Calcium at the crossroads of signaling. Plant Cell (Suppl.) 14:S401-417.

Schaller, A., and Oecking, C. 1999. Modulation of plasma membrane $\mathrm{H}^{+}$ATPase activity differentially activates wound and pathogen defense responses in tomato plants. Plant Cell 11:263-272.

Scheidle, H., Gross, A., and Niehaus, K. 2005. The Lipid A substructure of the Sinorhizobium meliloti lipopolysaccharides is sufficient to suppress the oxidative burst in host plants. New Phytol. 165:559-566.

Scofield, S. R., Tobias, C. M., Rathjen, J. P., Chang, J. H., Lavelle, D. T., Michelmore, R. W., and Staskawicz, B. J. 1996. Molecular basis of gene-for-gene specificity in bacterial speck disease of tomato. Science 274:2063-2065.

Scrase-Field, S. A., and Knight, M. R. 2003. Calcium: Just a chemical switch? Curr. Opin. Plant Biol. 6:500-506.

Sharma, P. C., Ito, A., Shimizu, T., Terauchi, R., Kamoun, S., and Saitoh, H. 2003. Virus-induced silencing of WIPK and SIPK genes reduces resistance to a bacterial pathogen, but has no effect on the INF1induced hypersensitive response (HR) in Nicotiana benthamiana. Mol. Gen. Genomics 269:583-591.

Simon-Plas, F., Elmayan, T., and Blein, J. P. 2002. The plasma membrane oxidase NtrbohD is responsible for AOS production in elicited tobacco cells. Plant J. 31:137-147.

Spoel, S. H., Koornneef, A., Claessens, S. M., Korzelius, J. P., Van Pelt, J. A., Mueller, M. J., Buchala, A. J., Metraux, J. P., Brown, R., Kazan, K., Van Loon, L. C., Dong, X., and Pieterse, C. M. 2003. NPR1 modulates cross-talk between salicylate- and jasmonate-dependent defense pathways through a novel function in the cytosol. Plant Cell 15:760-770.

Stamler, J. S., Lamas, S., and Fang, F. C. 2001. Nitrosylation: The prototypic redox-based signaling mechanism. Cell 106:675-683.

Stäb, M. R., and Ebel, J. 1987. Effects of $\mathrm{Ca}^{2+}$ on phytoalexin induction by fungal elicitor in soybean cells. Arch. Biochem. Biophys. 257:416-423. 
Takezawa, D. 2000. A rapid induction by elicitors of the mRNA encoding CCD-1, a $14 \mathrm{kDa} \mathrm{Ca}^{2+}$-binding protein in wheat cultured cells. Plant Mol. Biol. 42:807-817.

Tang, X., Frederick, R. D., Zhou, J., Halterman, D. A., Jia, Y., and Martin G. B. 1996. Initiation of plant disease resistance by physical interaction of avrPto and Pto kinase. Science 274:2060-2063.

Tavernier, E., Stallaert, V., Blein, J.-P., and Pugin, A. 1995. Changes in lipid composition in tobacco cells treated with cryptogein, an elicitor from Phytophthora cryptogea. Plant Sci. 104:117-125.

Thomma, B. P., Penninckx, I. A., Broekaert, W. F., and Cammue, B. P. 2001. The complexity of disease signaling in Arabidopsis. Curr. Opin. Immunol. 13:63-68.

Ton, J., Van Pelt, J. A., Van Loon, L. C., and Pieterse, C. M. 2002. Differential effectiveness of salicylate-dependent and jasmonate/ethylenedependent induced resistance in Arabidopsis. Mol. Plant-Microbe Interact. 15:27-34.

Torres, M. A., and Dangl, J. L. 2005. Functions of the respiratory burst oxidase in biotic interactions, abiotic stress and development. Curr. Opin. Plant Biol. 8:397-403.

Torres, M. A., Onouchi, H., Hamada, S., Machida, C., Hammond-Kosack, K. E., and Jones, J. D. G. 1998. Six Arabidopsis thaliana homologues of the human respiratory burst oxidase gp91phox. Plant J. 14:365-370.

Torres, M. A., Dangl, J. L., and Jones, J. D. G. 2002. Arabidopsis gp91phox homologues AtrbohD and AtrbohF are required for accumulation of reactive oxygen intermediates in plant defense response. Proc. Natl. Acad. Sci. U.S.A. 99:517-522.

Trevino Santa Cruz, M. B., Genoud, D., Metraux, J. P., and Genoud, T. 2005. Update in bioinformatics. Toward a digital database of plant cell signaling networks: Advantages, limitations and predictive aspects of the digital model. Phytochemistry 66:267-276.

Tronchet, M., Ranty, B., Marco, Y., and Roby, D. 2001. HSR203 antisense suppression in tobacco accelerates development of hypersensitive cell death. Plant J. 27:115-127.

van der Luit, A. H., Olivari, C., Haley, A., Knight, M. R., and A.J., T. 1999. Distinct signaling pathways regulate calmodulin gene expression in tobacco. Plant Physiol. 121:705-714.

Vandelle, E., Poinssot, B., Wendehenne, D., Bentéjac, M., and Pugin, A. 2006. Integrated signaling network involving calcium, nitric oxide, active oxygen species but not mitogen-activated protein kinases in BcPG1-elicited grapevine defenses. Mol. Plant-Microbe Interact. 19:429-440

Vandenabeele, S., Van Der Kelen, K., Dat, J., Gadjev, I., Boonefaes, T., Morsa, S., Rottiers, P., Slooten, L., Van Montagu, M., Zabeau, M., Inzé, D., and Van Breusegem, F. 2003. A comprehensive analysis of hydrogen peroxide-induced gene expression in tobacco. Proc. Natl. Acad. Sci. U.S.A. 100:16113-16118.

Wandrey, M., Trevaskis, B., Brewin, N., and Udvardi, M. K. 2004. Molecular and cell biology of a family of voltage-dependent anion channel porins in Lotus japonicus. Plant Physiol. 134:182-183.

Ward, J. M., Pei, Z.-M., and Schroeder, J. I. 1995. Roles of ion channels in initiation of signal transduction in higher plants. Plant Cell 7:833-844.

Wendehenne, D., Pugin, A., Klessig, D. F., and Durner, J. 2001. Nitric oxide: Comparative synthesis and signaling in animal and plant cells. Trends Plant Sci. 6:177-183.

Wendehenne, D., Lamotte, O., Frachisse, J.-M., Barbier-Brygoo, H., and Pugin, A. 2002. Nitrate anion efflux is an essential component of the cryptogein signaling pathway leading to defense responses and hypersensitive cell death in tobacco. Plant Cell 14:1937-1951.

Wendehenne, D., Durner, J., and Klessig, D. F. 2004. Nitric oxide: A new player in plant signaling and defence responses. Curr. Opin. Plant Biol. 7:449-455.

White, P. J., and Broadley, M. R. 2003. Calcium in plants. Ann. Bot. (Lond). 92:487-511.

Wright, C. A., and Beattie, G. A. 2004. Pseudomonas syringae pv.tomato cells encounter inhibitory levels of water stress during the hypersensi- tive response of Arabidopsis thaliana. Proc. Natl. Acad. Sci. U.S.A. 101:3269-3274.

Xing, T., Higgins, V. J., and Blumwald, E. 1996. Regulation of plant defense response to fungal pathogens: Two types of protein kinases in the reversible phosphorylation of the host plasma membrane $\mathrm{H}^{+}$-ATPase. Plant Cell 8:555-564.

Xing, T., Wang, X. J., Malik, K., and Miki, B. L. 2001. Ectopic expression of an Arabidopsis calmodulin-like domain protein kinase-enhanced NADPH oxidase activity and oxidative burst in tomato protoplasts. Mol. Plant-Microbe Interact. 14:1261-1264.

Xiong, T. C., Jauneau, A., Ranjeva, R., and Mazars, C. 2004. Isolated plant nuclei as mechanical and thermal sensors involved in calcium signaling. Plant J. 40:12-21.

Yamakawa, H., Mituhara, I., Ito, N., Seo, S., Kamada, H., and Ohashi, Y. 2001. Transcriptionally and post-transcriptionally regulated response of 13 calmodulin genes to tobacco mosaic virus-induced cell death and wounding in tobacco plant. Eur. J. Biochem. 268:3916-3929.

Yamasaki, H., and Sakihama, Y. 2000. Simultaneous production of nitric oxide and peroxynitrite by plant nitrate reductase: In vitro evidence for the NR-dependent formation of active nitrogen species. FEBS (Fed. Eur. Biol. Soc.) Lett. 468:89-92.

Yang, K. Y., Liu, Y. D., and Zhang, S. Q. 2001. Activation of a mitogenactivated protein kinase pathway is involved in disease resistance in tobacco. Proc. Natl. Acad. Sci. U.S.A. 98:741-746.

Yap, Y.-K., Kodama, Y., Waller, F., Chung, K. M., Ueda, H., Nakamura, K., Oldsen, M., Yoda, H., Yamaguchi, Y., and Sano, H. 2005. Activation of a novel transcription factor through phosphorylation by WIPK, a wound-induced mitogen-activated protein kinase in tobacco plants. Plant Physiol. 139:127-137.

Yoon, G. M., Cho, H. S., Ha, H. J., Liu, J. R., and Pai, H. P. 1999. Characterization of $N t C D P K 1$, a calcium-dependent protein kinase gene in Nicotiana tabacum, and the activity of its encoded protein. Plant Mol. Biol. 39:991-1001.

Yoshioka, K., Sugie, K., Park, H. J., Maeda, H., Tsuda, N., Kawakita, K., and Doke, N. 2001. Induction of plant gp91 phox homolog by fungal cell wall, arachidonic acid, and salicylic acid in potato. Mol. PlantMicrobe Interact. 14:725-736.

Yoshioka, H., Numata, N., Nakajima, K., Katou, S., Kawakita, K., Rowland, O., Jones, J. D., and Doke, N. 2003. Nicotiana benthamiana gp91(phox) homologs $N b r b o h A$ and $N b r b o h B$ participate in $\mathrm{H}_{2} \mathrm{O}_{2}$ accumulation and resistance to Phytophthora infestans. Plant Cell 15:706-718.

Zeidler, D., Zähringer, U., Gerber, I., Dubery, I., Hartung, T., Bors, W., Hutzler, P., and Durner, J. 2004. Innate immunity in Arabidopsis thaliana : Lipopolysaccharides activate nitric oxide synthase (NOS) and induce defense gene. Proc. Natl. Acad. Sci. U.S.A. 101:15811-15816.

Zhang, C., Czymmek, K. J., and Shapiro, A. D. 2003. Nitric oxide does not trigger early programmed cell death events but may contribute to cell-to-cell signaling governing progression of the Arabidopsis hypersensitive response. Mol. Plant-Microbe Interact. 16:962-972.

Zhang, S., Du, H., and Klessig, D. F. 1998. Activation of the tobacco SIP kinase by both a cell wall-derived carbohydrate elicitor and purified proteinaceous elicitins from Phytophthora spp. Plant Cell 10:435-449.

Zimmermann, S., Nürnberger, T., Frachisse, J.-M., Wirtz, W., Guern, J., Hedrich, R., and Scheel, D. 1997. Receptor-mediated activation of a plant $\mathrm{Ca}^{2+}$-permeable ion channel involved in pathogen defense. Proc. Natl. Acad. Sci. U.S.A. 94:2751-2755.

Zipfel, C., Robatzek, S., Navarro, L., Oakeley, E. J., Jones, J. D. G., Felix, G., and Boller, T. 2004. Bacterial disease resistance in Arabidopsis through flagellin perception. Nature 428:764-767.

\section{AUTHOR-RECOMMENDED INTERNET RESOURCE}

Purdue University's PlantsP: Functional Genomics of Plant

Phosphorylation website: plantsp.genomics.purdue.edu 